\title{
Aksjologiczne problemy związane z najnowszą literaturą polską. Casus prozy Jakuba Żulczyka
}

Gdy zechce kochać - ja mu dam łabędzie

Głosy, ażeby miłość swoję śpiewał;

Kiedy kląć zechce - przeze mnie kląć będzie;

Gdy zechce płonąć - ja będę rozgrzewał; Ja go powiodę, gdzie Bóg - w bezmiar - wszędzie. (Juliusz Słowacki, Beniowski, Pieśń V, ww. 525-529, BN seria I nr 13/14, Wrocław 1996, s. 151)

- Kelly Family... ich było za dużo i byli tacy świńscy. Poza tym, to już nie jest ta niewinność. Rozumiesz? Niewinność! (Jakub Żulczyk, Zrób mi jakąś krzywdę, Warszawa 2018, s. 111)

\section{"Lektury młodzieżowe"}

ednym z poczytniejszych polskich pisarzy debiutujących na początku XXI wieku jest Jakub Żulczyk, autor m. in. takich powieści jak Zrób mi jakąś krzywdę... czyli wszystkie gry video sa o miłości (2006), Radio Armageddon (2008), Instytut (2010), Zmorojewo (2011), Świątynia (2011), Ślepnąc od świateł (2014) czy Wzgórze psów (2017). Czytają go dorośli, ale również młodzież. Jego książki, jak wolno przypuszczać, nigdy nie wejdą do kanonów lektur szkolnych, niemniej jednak są przez uczniów - ku zadowoleniu rodziców i nauczycieli - czytane. Utarło się bowiem fałszywe mniemanie, że najważniejsze jest, aby młodzież czytała,

\footnotetext{
* Dr нав. Dorota Kulczycka, PRof. UZ - Zakład Teorii Literatury i Krytyki Literackiej, Instytut Filologii Polskiej, Uniwersytet Zielonogórski; e-mail:D.Kulczycka@ifp.uz.zgora.pl
} 
nieistotne jakq literature, ale oby tylko po niq sięgała ${ }^{1}$ Z jednej strony dostępność literatury, a z drugiej - nacisk na indywidualny rozwój każdego człowieka, wolność wyboru określonych „dóbr” kulturalnych sprzyjają owym tendencjom afirmacji każdego bez wyjątku czytelnictwa. Przemilcza się natomiast szkodliwość lektury pewnych gatunków literackich czy twórczości wychodzącej spod pióra niektórych pisarzy. O wiele bowiem trudniejszym zadaniem jest przestrzeganie przed antywartościami tkwiącymi we współczesnej kulturze niż mówienie o wartościach wyższych i najwyższych obecnych w czyjejś twórczości ${ }^{2}$. I choć temat antywartości lansowanych przez współczesnych pisarzy jest niewdzięczny, konotujący ryzyko ostrej dyskusji (z posądzeniem o malkontenctwo, indoktrynację lub o tendencje cenzorskie), właśnie nim - jako niezwykle aktualnym - autorka chciałaby się w niniejszym tekście zająć. Przykładem jest reprezentatywna pod tym względem proza Jakuba Żulczyka ${ }^{3}$. W analizie i interpretacji tekstów literackich nieodzowne jest cytowanie. Wskazanie elementów "gorszących" w tej prozie jest o tyle kłopotliwe, że pisanie o nich może stanowić - niestety - pewną formę demoralizacji - a z innej strony: przyzwolenia, propagowania czy też kryptoreklamy.

Proza Żulczyka nie jest zjawiskiem odosobnionym. Reprezentuje bowiem szeroką gamę utworów zalewających dziś rynek księgarski. Dlaczego młodzież ją czyta? Czyni tak ze względu na aktualność podejmowanej problematyki (np. historyczność jest czymś zupełnie obcym autorowi), na bogactwo skojarzeń ze współczesną popkulturą, na zdawkową psychologizację i częste utożsamianie narratora z bohaterem jako zwykłym, pełnym słabości człowiekiem. Młode

${ }^{1}$ Istnieje powszechne hasło nawołujące do lektury, aby się rozwijać i aby poznawać siebie wedle znanych hermeneutyce słów $\mathrm{z}$ wyroczni delfickiej: cognosce te ipse. Funkcjonuje też powiedzenie, że książka jest przyjacielem człowieka, a także zapożyczone od Umberto Eco „Kto czyta książki, żyje podwójnie". Szkoły i biblioteki organizują często konkursy na wymyślanie haseł upowszechniających czytelnictwo. Zob. np.: http://bibliotekachojnice.pl/hasla-promujace-czytanie-ksiazek/; https://zsgsiedlec.wordpress.com/2016/05/03/nagrodzone-hasla-reklamujace-biblioteke-i-czytanie/; [dostęp: 2018-06-21]. Zob. też np.: A. Belcer, Promowanie czytelnictwa i bibliotek z pomystem: przegląd wybranych akcji czytelniczych, „Podkarpackie Studia Biblioteczne”, $\mathrm{Nr} 4$ (2015), http://psb.ur.edu.pl/ sites/default/files/pdf/promowanie_czytelnictwa_i_bibliotek_z_pomyslem.pdf, [dostęp: 2018-06-21].

${ }^{2}$ Kwestię aksjologii obecną w twórczości artysty szczególnie wyczulonego na wartości najwyższe - Cypriana Norwida badał np. Stefan Sawicki. Zob. tenże, Chrześcijańskie wartości poezji Norwida, Lublin 1986; tenże, Wartość - sacrum - Norwid, Lublin 1994. Zob. też: O wartościowaniu w badaniach literackich, pod red. S. Sawickiego, W. Panasa, Lublin 1986. Polska poezja romantyczna szczególnie nakierowana była na świat wartości duchowych i sakralnych. Dziś przeżywają one w kulturze (zwłaszcza w kulturze popularnej, masowej) - dotkliwy kryzys.

${ }^{3}$ Nie chodzi jednak o ocenzurowanie czy o indoktrynację, ale o szukanie prawdy i stwierdzenie istnienia problemu czy też - pewnego zjawiska w historii literatury. Skoro Maria Gołaszewska napisała książkę Estetyka i antyestetyka (Warszawa 1984) oraz wydała pracę zbiorową pod swoją redakcją zatytułowaną: Kryzys estetyki? (Kraków 1983), inni mogą podjąć się tematu kryzysu etyki, widząc ów dotkliwy brak we współczesnej polskiej epice. 
pokolenie sięga po nią, gdyż - jak sądzi sam autor - odnajduje w niej siebie ${ }^{4}$. Poza tym w polskiej literaturze nie za bardzo widzi alternatywy $\mathrm{y}^{5}$. W prozie zachodniej są promowane wartości, co nie umniejsza faktu, że ciekawie się ją czyta. Czegoś takiego brakuje literaturze polskiej. Młodzi czytają Żulczyka również dla mocnych wrażeń, dlatego właśnie, że pisarz ten bulwersuje, skandalizuje, poraża złem. Lektura książek pozostających poza ramami edukacji szkolnej jest bardziej kusząca niż tych, które uwzględniają programy szkolne. Tymczasem pedagodzy i dydaktycy powinni przyglądać się raz po raz właśnie nie-lekturom szkolnym, gdyż prawdą jest, że młodzież nieraz sięga po książki nienakazywane, a może nawet - gdyby takie obecnie istniały - książki „zakazane”, co nie pozostaje bez echa na (późniejszych) ich zachowaniach i na formowanym w nich światopoglądzie (o czym będzie jeszcze mowa). O owej poczytności, a także o akceptacji ze strony nauczycieli, mówi sam Żulczyk w wywiadzie przeprowadzonym z nim przez Grzegorza Wysockiego:

\section{W jakim wieku są twoi czytelnicy? 20 plus czy minus? \\ No chyba jednak plus. Mam wrażenie, że wielu czytelników rośnie wraz ze mną. Chociaż czyta mnie też sporo maturzystów. Wiem, bo ciągle mi piszą: „Mówiłam o panu na maturze i dostałam piątkę". Starsi też czytają, nawet w wieku naszych rodziców, koło sześćdziesiątki. Ale jednak głównie młodsi. Część z nich traktuje cię jako autorytet, wypisują sobie z książek mądrości, szerują twoje złote myśli... ${ }^{6}$.}

Zauważmy: nauczyciele cieszą się, że młodzież w ogóle cokolwiek czyta i nieważne jest, czy są to utwory złe, gorszące i deprawujące ${ }^{7}$. Z drugiej strony stają przed faktem dokonanym: młodzież niezależnie od wyrażanej przez dorosłych aprobaty czy dezaprobaty i tak będzie sięgać po tę prozę - z zastrzeżeniem, że

${ }^{4}$ Por. G. Wysocki, Nie jestem polskim Kingiem ani Tarantino. Jak to w ogóle brzmi?, [wywiad z Jakubem Żulczykiem], 10 listopada 2017, https://magazyn.wp.pl/artykul/jakub-zulczyk-nie-jestempolskim-kingiem-ani-tarantino-jak-to-w-ogole-brzmi, [dostęp: 2018-03-12].

${ }^{5}$ Narracja Żulczykowych powieści (nie bacząc na jej dłużyzny) jest płynnie prowadzona. Język - pomijając fakt, że bardzo często ordynarny - nie wydaje się sztuczny, utrudniający czytanie, ale potoczysty i w pewnym sensie bogaty, uwzględniający nowoczesne nazewnictwo i aktualne sposoby wyrażania się zwłaszcza „nizin moralnych”. Wielu odbiorcom czyta się ową prozę dobrze i to jest jej „pułapką”. Co w tym „fatalnym zauroczeniu” może być niebezpieczne, to Żulczykowa nauka najrozmaitszych form wulgaryzmów i sposobów poniżającego traktowania drugiego człowieka. Taka proza nie buduje, nie udoskonala człowieka, nie podnosi na duchu, ale - czego próbuję dowieść w niniejszym artykule - niszczy.

${ }^{6}$ G. Wysocki, Nie jestem polskim Kingiem ani Tarantino... Informację o poczytności prozy Żulczyka wśród maturzystów sam autor potwierdza w wywiadzie Dzięki odstawieniu używek odzyskatem prace (https://www.youtube.com/watch?v=YRLbV947O7s - dostęp: 2018-05-11).

${ }^{7}$ Niestety, podobną sytuację miałam jako nauczyciel akademicki - nie zwróciłabym uwagi na prozę Żulczyka, gdyby nie dydaktyczny przymus przyjrzenia się temu, z czego moi studenci chcą pisać prace magisterskie. 
duży odsetek młodzieży w ogóle nie czyta książek ${ }^{8}$. Problem zatem wydaje się tkwić gdzie indziej: po pierwsze w promocji literatury służącej wartościom, a po drugie - w uczeniu młodzieży świadomego, refleksyjnego czytania. W ten sposób zapobiegłoby się najbardziej zgubnym skutkom karmienia się przez młodych „antywartościami”, pod warunkiem, że dorośli pełniący rolę odpowiedzialnych wychowawców sami mieliby zdrowy kręgosłup moralny. Niestety: po pierwsze nie wszyscy posiadają wysoką samoświadomość i świadomość wartości bądź bezwartościowości literatury9; czytają to, co im ktoś poradzi, byle nie klasykę; po drugie: ci, którzy lubią wulgarne słownictwo i ostre sceny będą dalej taką literaturę, jako im odpowiadającą, czytać, ze szczególnym zwracaniem uwagi na wyżej wymienione aspekty. Nawet gdybyśmy nauczyli młodzież refleksyjnego, świadomego czytania, pozostaje inny problem: zapadania tysięcy wulgaryzmów obecnych w tej prozie w różnych - głębokich i płytkich strukturach pamięci, lokowania owych słów i obrazów w świadomości i podświadomości, niezależnie nawet od woli czytającego. Owe torowanie i modelowanie będą ważnym punktem niniejszych rozważań.

Jakub Żulczyk w swojej prozie raz po raz podejmuje problemy związane ze szkołą. Niekiedy dokonuje - posługując się swoimi narratorami-bohaterami swoistej charakterystyki nauczycieli. W powieści dla młodzieży - w Zmorojewie polonistka Agata Florek jest przedstawiona $\mathrm{z}$ humorem, ale wyjątkowo - jak na prozę Żulczyka - niewinnie (zob. Z, s. 20-21 ${ }^{10}$ ). Szczególnie rażący brak szacunku wobec nauczyciela ujawniony jest w powieści Instytut. Agnieszka, matka nastolatki, wezwana jest do szkoły, gdyż jej córka pobiła kolegę za to, że ten jej groził, iż wrzuci do Internetu odpowiednio spreparowane zdjęcia. Tymczasem w narracji prowadzonej w całej powieści przez ową matkę padają najbardziej ordynarne inwektywy pod adresem nauczycielki. Nie inaczej się o niej mówi,

${ }^{8}$ Według sondaży z 2016 roku 86 \% młodzieży czyta książki (a zatem 14 \% nie czyta niczego, nawet lektur szkolnych), gdy tymczasem tylko 37 \% całego społeczeństwa sięga po literaturę. Zob.: „Gazeta Międzyszkolna”, 8 sierpnia 2016, http://www.gazetamiedzyszkolna.pl/2016/08/08/ czytelnictwo-az-86-mlodych-ludzi-czyta-ksiazki/, [dostęp: 2018-04-05]. Dane o czytelnictwie potwierdzają raporty Biblioteki Narodowej przytoczone przez „Newsweek Polska”, 21 kwietnia 2017. Zob.: http://www.newsweek.pl/styl-zycia/raport-czytelnictwa-w-polsce-ile-ksiazek-czytajapolacy-,artykuly,409201,1.html, [dostęp: 2018-04-05].

9 Należy zresztą za Władysławem Stróżewskim wyróżnić trzy sposoby istnienia, urzeczywistniania się wartości: 1) być wartością; 2) mieć wartość; 3) być (czymś) wartościowym. (tenże, $W$ kręgu wartości, Kraków 1992, s. 60). Proza Żulczyka wymagałaby konfrontacji z każdą z tych płaszczyzn - w niniejszym artykule najbardziej brany pod uwagę jest aspekt drugi, gdzie słowo „mieć” można też zastąpić czasownikiem „lansować”, a pojęcie „wartości” - opatrzyć przedrostkiem „anty-”.

${ }^{10}$ Aby nie mnożyć przypisów aluzje i wszystkie cytaty z utworów Jakuba Żulczyka będą opatrywane następującymi skrótami, ewentualnie z podaniem strony: Zmjk - Zrób mi jakąś krzywdę, Warszawa 2018; RA - Radio Armageddon, Warszawa 2015; I - Instytut, Kraków 2010; Z - Zmorojewo. Powieść fantastyczno-przygodowa, Warszawa 2011; Śoś - Ślepnąc od światet, Warszawa 2015; Wp - Wzgórze psów, Warszawa 2017. 
jak właśnie - konsekwentnie - w jeden, wulgarny sposób. Trzeba też zwrócić uwagę na serial Belfer, do którego Żulczyk wraz z Moniką Powalisz napisali scenariusz. Uczniowie w tym filmie mają - podobnie jak dorośli - naganne słownictwo, które stosują m.in. pod adresem nauczyciela.

W wywiadzie Żulczyk przyznaje, że w swoich powieściach stwarza światy, „które w jakiejś mierze próbują być zdjęciem rzeczywistości, ale jednocześnie są też przerysowane, komiksowe [...]. Delikatnie i celowo przegięte. To świadomy zabieg pisarski"11. W kontekście owej deklaracji można się zapytać: a gdyby tak czytać dzieła Żulczyka jak wielką metaforę, jako objective correlative współczesności? Może owe obrazoburcze powieści są Gargantua i Pantagruelem XXI wieku - sztuką ludyczną, rubaszną, kiedyś zakazaną, niekanoniczną, a jednak istniejącą? ${ }^{12}$. Owszem, taką ta proza też jest. Ale to jej nie usprawiedliwia - nie czyni „nauczycielką życia”, tą, która pozwala lepiej rozumieć siebie i drugich, żyć wartościami.

\section{Loci qui sollicitudinem afferunt w prozie Jakuba Żulczyka}

Pisarz wszystko w swoich powieściach zdeformował, wyostrzył i wyolbrzymił, ale właśnie w takich aspektach, jak poniższe, owa tendencja do przedstawiania świata w krzywym zwierciadle może budzić niepokój. Przede wszystkim więc razi:

- wulgaryzacja języka. Słownictwo (określane niekiedy jako utrzymane w poetyce art-brut bądź punk-rocka), jakim posługuje się Żulczyk pod osłoną narracji 1-osobowej prowadzonej przez swych (często zdegenerowanych) bohaterów, jest - podobnie jak pewien typ scenariuszy polskich filmów i seriali ${ }^{13}$ - silnie

${ }^{11}$ G. Wysocki, Nie jestem polskim Kingiem ani Tarantino...

${ }_{12}$ Badacze podobnie próbują znaleźć sens twórczości Markiza de Sade’a. Roger Shattuck w swojej książce Wiedza zakazana... pisze o skrajnie różnych stanowiskach wobec gorszyciela, broniąc jednocześnie tezy, że „nie powinniśmy palić Sade’a ani też sławić jako nowego klasyka moralnego wyzwolenia”. Powołuje się na rozmaite konstatacje, $\mathrm{m}$. in. Rolanda Barthesa, który uważał dzieła Sade’a za „czystą poezję” dającą czytelnikowi wielką przyjemność, za popis „sztuki pisania” (R. Shattuck, Wiedza zakazana. Od Prometeusza do pornografii, przekład M. Borowska, Kraków 1999, r. VII Boski Markiz, s. 348 [całość: s. 275-360]).

${ }_{13}$ Mam na uwadze przede wszystkim filmy i seriale w reżyserii Patryka Vegi, do których tenże pisuje często własne scenariusze. W epatowaniu wulgaryzmami dorównują one scenariuszom wychodzącym spod pióra omawianego tu pisarza. A zatem mechanizm „sprzężenia zwrotnego”, o którym piszę pod koniec niniejszego artykułu, dotyczy również filmów. Konsekwencje moralnie popularności tego typu obrazów są o wiele groźniejsze, gdyż u odbiorcy atakowane są dodatkowo zmysły wzroku i słuchu. Poza tym więcej osób (również młodych) ogląda filmy, niż oddaje się lekturze np. omawianej tu prozy. „Siła rażenia” audiowizualnych produkcji jest też większa. Co interesujące, Polonia, chodząc do kin na premiery produkcji polskich i kupując nowości wydawnicze młodych rodzimych twórców, odbiera je jako „kulturę” i „prawdę” o tym, co dzieje się w kraju. 
zwulgaryzowany. Właściwy nie tylko temu autorowi „upadek w wulgaryzację" wydaje się być symptomem pewnej mody oraz wynikiem jednostronnej diagnozy społeczeństwa. Nie wydaje się, aby dystans niezbędny przy diagnozowaniu dotyczył autora, który chociażby w cytowanym wywiadzie używa wulgaryzmów, a na zarzut, że jego proza jest obsceniczna, odpowiada, jakoby była to jego naturalna maniera wyrażania się:

No wiesz, zobaczyłem jakąś masę anonimowych recenzji pisanych z fejkowych kont o tym, że książka jest wulgarna i że są w niej brzydkie wyrazy i ludzi bardzo to drażni. Jak ktoś kupuje moją książkę i ma pretensje, że momentami jest brutalna albo wulgarna, to tak, jakby miał pretensje do kota, że miauczy.

Czyli de facto chciałeś powiedzieć takim czytelnikom, żeby się, delikatnie mówiąc, od... gonili?

Nie. Chciałem powiedzieć - nie miejcie pretensji do kota, że miauczy ${ }^{14}$.

Niemalże każda strona powieści Żulczyka (wyłączając „horror” dla dzieci i młodzieży - Zmorojewo, choć i tam pojawiają się owe „brzydkie słowa”) znaczona jest wiązkami niewybrednych słów. Zresztą wszystkie ludzkie zachowania, nie tyko werbalne, autor prezentuje w sposób karykaturalny i wulgarnie przerysowany jako patologiczne $\mathrm{i}-\mathrm{w}$ konsekwencji - patogenne. Można zaryzykować twierdzenie, że w ten sposób na czytelnikach stosowana jest „przemoc symboliczna", o której niegdyś - co prawda w innym kontekście - pisał Pierre-Félix Bourdieu. Pisarstwo tak okaleczone stanowi pewną formę władzy i opresji. O języku jako środku do stosowania przemocy w mediach i o jej długotrwałych skutkach pisze też współczesna znana niemiecka psycholog - Barbara Krahé15.

- wszechobecność pornografii. Filmy pornograficzne to stały repertuar w Żulczykowej filmografii. Aluzje do filmów porno są w prozie autora Ślepnąc od świateł szczególnie częste. Nie są od nich wolne nawet powieści dedykowane nieletnim: Zrób mi jakąś krzywdę oraz Zmorojewo. W tym kontekście można powiedzieć, że informacje o pornograficznych czasopismach (z podanymi nieraz tytułami - zob. np. Wp, s. 77) oraz o filmach i zdjęciach pornograficznych (z zaznaczonymi nieraz, jak w Radiu Armageddon na s. 32, stronami internetowymi bądź tytułami owych produkcji) stanowią tylko żałosne dopełnienie reszty. Okazuje się, że wskazane przez autora witryny autentycznie istnieją - wystarczy,

${ }^{14}$ G. Wysocki, Nie jestem polskim Kingiem ani Tarantino. Jak to w ogóle brzmi?... Już w 2008 r. w wywiadzie danym dla „Wysokich Obcasów” Żulczyk operował niezwykle ordynarnym językiem, przyznawał się też do oglądania pornografii. Zob.: Kobieta śmierdzaca człowiekiem, [z Jakubem Żulczykiem] rozmawiały A. Drotkiewicz i A. Dziewit-Meller, „Wysokie Obcasy”, 30 listopada 2008, http://www.wysokieobcasy.pl/wysokie-obcasy/1,96856,5992077,Kobieta_smierdzaca_czlowiekiem. html, [dostęp: 2018-05-06].

${ }^{15}$ Zob.: B. Krahé, Agresja, przekł. J. Suchecki, Gdańsk 2005, s. 90-115 i 128. 
że młody czytelnik „wygugluje” sobie ich nazwy, a pokażą mu się czy to informacje czy te $\dot{z}-w$ grafice - niekontrolowane przez nikogo obrazy. Znamienne też, że ulubioną stacją telewizyjną bohaterów - narratorów Żulczyka jest stacja dla młodzieży, notabene zabraniająca wstępu jakichkolwiek treści chrześcijańskich - MTV. Tutaj jego bohaterowie także mieliby oglądać pornografię. Autor, aby nakierować uwagę właśnie na nią, jako rzekomo główną i niezbędną rozrywkę dorastających Polaków, przypisuje owej stacji również sfingowane przez siebie tytuły. W Radiu Armagedon pisze: „Fala (chłopców - przyp. D.K.) szła do domu, by grać na komputerze, oglądać filmy porno i Taniec $z$ gwiazdami i Przeleć moją mamę na MTV" (RA, s. 177). W rzeczywistości nie ma takiego, jak ostatni ze wspomnianych, filmu, ale w Internecie roi się od pornograficznych nagrań z podobnym, choć jeszcze ordynarniejszym czasownikiem w tytule. We Wzgórzu psów Justyna porównuje się do aktorki szczególnie wulgarnych obrazów porno (zob. Wp, s. 51), ale stałym użytkownikiem filmów oraz czasopism pornograficznych jest jej mąż - Mikołaj (zob. np. Wp, s. 58, 77 i in.). Bohater, nastawiony na egoistyczny hedonizm, od wczesnej młodości oglądający pornografię i masturbujący się z myślą o ponętnych koleżankach, nie będzie umiał - gdy taki się pojawi - pielęgnować realnego związku. I rzeczywiście małżeństwo Mikołaja z Justyną szybko się rozpadnie. Żona wróci do swojego szefa, a on coraz intensywniej będzie przekonywał się, jak podobna do Darii, pierwszej jego dziewczyny, jest jej siostra - Kaśka. Wartości wyższe i najwyższe nie mają tu jakiegokolwiek znaczenia.

$\mathrm{W}$ niewybrednej scenie $\mathrm{z}$ owej powieści - $\mathrm{w}$ chatce-kopulatce - mieszkaniu należącym do Wariata, Agata, Grzesiek i inni znajomi zastali Bylińskiego (Byla) z małolatą Magdą. Bylu każe się jej czym prędzej ubrać, a braciom Głowackim -

Pokazuje stojące na stole napoczęte butelki słodkiego, różowego carlo rossi i szereg zamkniętych puszek taniego piwa. Agata kręci głową. [...] Pod stolikiem jest sterta „Playboyów", magazynów fitness, parę DVD z filmami porno ze stacji benzynowej, zapachowa świeczka. W kącie leżą ciśnięte ciuchy. (Wp, s. 446)

Uzmysłowianie w detalach, co dzieci robiły w owym domu i towarzyszące wspomnieniom Mikołaja przekleństwa, stanowią preludium do obrazu kolejnych „niekontrolowanych” zachowań bohatera: $m$. in. zdrady małżeńskiej ze wspomnianą siostrą pierwszej dziewczyny - Kaśką wobec też zdradzającej go żony. Pocieszenie zdradzonemu ma więc rzekomo przynieść rewanż według ironicznie brzmiącej zasady: „odpłacić się pięknym za nadobne”. Idzie to w parze z trendami obecnymi we współczesnej obyczajowości, podsycanymi jeszcze bardziej przez kulturę masową (dość przypomnieć komedię romantyczną Porady na zdrady, reż. Ryszard Zatorski, Polska 2017). 
Z tego oraz wielu różnych innych powodów książki Żulczyka można uznać za swoiste instruktaże do czynienia zła i swoiste źródło demoralizacji. Problem owej demoralizacji - płynącej najprzeróżniejszymi kanałami, również - niestety - przez taką literaturę, tym bardziej wydaje się jaskrawy, gdy uwzględnimy najnowsze raporty. Otóż $\mathrm{m}$. in. coraz powszechniej znana organizacja CitizenGo 10 marca 2018 r. informuje o inicjatywie „Misji Gabriela”, która walczy o niedostępność pornografii wśród nieletnich. Stowarzyszenie to zbiera podpisy pod petycją do Ministra Cyfryzacji, informując m. in., że:

Od 40 do 50 procent młodzieży sięga po pornografię. Oznacza to, że co drugie (!) dziecko styka się z pornografią. Z badań przeprowadzonych przez Instytut Profilaktyki Zintegrowanej (IPZ) wśród gimnazjalistów wiemy, że 61 procent chłopców i 42 procent dziewcząt pierwszy kontakt z pornografią miało już w wieku 12 lat. Aż 46 procent chłopców w gimnazjum sięga po pornografię od kilku do kilkudziesięciu razy w miesiącu, a 15 procent zadeklarowało oglądanie pornografii ponad 30 razy w miesiącu. Badanie przeprowadzono na ponad 10,8 tys. uczniów II i III klas gimnazjum z 10 województw.

[...] Aż 80 procent smartfonów, z których korzysta młodzież, nie posiada zabezpieczeń przed treściami pornograficznymi ${ }^{16}$.

Nieco wcześniej w czasopiśmie „Do Rzeczy” (z 8-14 stycznia 2018 r.) pojawił się artykuł Agnieszki Niewińskiej, wyrażającej nadzieję na pozytywne rezultaty kampanii i jeśli nie zablokowanie to przynajmniej ograniczenie dostępu młodzieży do pornografii w Internecie. Autorka wierzy, nie bacząc na spustoszenie moralne, jakie istnieje już w średnim pokoleniu nie tylko zresztą wśród Polaków, że nagłośnienie problemu uwrażliwi rodziców i zainteresuje ich potencjalnym zagrożeniem, jakie niosą ze sobą nowoczesne środki przekazu. Podaje, że według seksuologa doktora Bogdana Stelmacha pornografia przez Internet deformuje psychikę i umysł o wiele silniej niż przez jakiekolwiek inne jej źródła (częstotliwość bodźców w danej jednostce czasu jest o wiele większa). Przypomina najnowsze wyniki sondaży przeprowadzonych $\mathrm{m}$. in. w liceach, pisząc o zatrważających statystykach oraz o podobnych, jak w raporcie „Misji Gabriela”, konsekwencjach oglądalności pornografii (dewiacje, nasilające się uzależnienie od masturbacji i samej pornografii, niezdolność do prawdziwej miłości, niemożność założenia rodziny bądź wytrwania w niej itd. ${ }^{17}$.

${ }^{16}$ Chrońmy dzieci i młodzież przed pornografia, http://www.citizengo.org/pl/157711-do-ministra-cyfryzacji-szanowny-panie-ministrze-w-obliczu-ogolnej-dostepnosci-internetu-bez, [dostęp: 2018-03-10].

17 A. Niwińska, Ocalić od porno, „Do Rzeczy. Tygodnik Lisickiego”, nr 2/255, z 8-14 stycznia 2018 r., s. 36-37. Por. np. dość kontrowersyjnie zatytułowany artykuł: Bogdan Stelmach, seksuolog: Pornografia powoduje przewlekłą chorobę mózgu, 10 lutego 2017, http://telewizjarepublika.pl/ bogdan-stelmach-seksuolog-pornografia-powoduje-przewlekla-chorobe-mozgu,44417.html, [dostęp: 
To prawda: pornografia jest bardzo łatwo dostępna w Internecie, o czym Żulczyk doskonale wie. Zamiast odwracać uwagę młodych na inne sprawy, przekonuje o jej powszechności i podaje dzieciom oraz młodzieży linki do tych stron. Zresztą autor w swoich powieściach nie poprzestaje na aluzjach do mediów z pornografią i na częstych informacjach o korzystaniu z nich przez swoich bohaterów. W swojej debiutanckiej powieści adresowanej do nieletnich - Zrób mi jakąś krzywdę - wprowadza scenę nakręcania filmiku porno przez niemłodą już parę małżeńską na oczach głównych bohaterów. Każe też owym protagonistom, szczególnie zaś piętnastolatce Kasi okazywać entuzjazm wynikający z kontaktu z tego typu „filmowcami” oraz zaprzyjaźnić się z tyle rubaszną, co nad wyraz słodką "gwiazdą porno". Język i obrazowanie w niemalże całej prozie Żulczyka - jak również u innych polskich autorów XXI wieku - są także „pornograficzne”. Toteż kolejnym źródłem niepokoju jest:

- niezwykle częste mówienie o kwestiach erotycznych, ponadto w sposób wulgarny i obsceniczny. Wszelkie relacje damsko-męskie są w światach przedstawionych tych powieści bezczeszczone, hańbione i zohydzane. Nie ma w tej twórczości pięknej miłości, budowanej na wierności i szacunku. W ich miejscu pojawia się doraźne użycie, wykorzystanie, wzgarda i nienawiść podsycana wulgarnym słownictwem - stałym elementem na prawie każdej stronie tej prozy. O sprawach intymnych mówi się w sposób ohydny. Jeśli nawet we wspomnianej powieści rzekomo dla młodzieży pojawiają się delikatniejsze elementy, przeplatane są motywami wulgarnymi, a całość kończy się kontrowersyjnym pod względem etycznym akordem, traktowanym oczywiście jako happy-end. Jaka strawa duchowa, takie życie. Jeśli bohaterowie karmili się od niemalże dzieciństwa pornografią, należy wątpić, by umieli kształtować harmonijne i dobre relacje z drugą płcią ${ }^{18}$. Nie tylko wydziedziczeni ze świata wartości są chłopcy i mężczyźni. Moralna gangrena dotyka też dziewczyn i kobiet występujących w dziełach Żulczyka.

Kolejnym destrukcyjnym rysem, zresztą wiążącym się z poprzednimi kwestiami, jest:

2018-06-20]. Większość niewybrednych wpisów, dokonanych przez dorosłych, jakie pojawiają się pod tym artykułem, każe wątpić w możliwość ochrony dzieci przed deprawacją przez tak właśnie uformowanych rodziców i dziadków.

${ }^{18}$ W przywołanym raporcie „Misji Gabriela” czytamy: „Na skutki pornografii nie trzeba długo czekać. Młodzież uzależnia się od widzianych obrazów, szuka coraz intensywniejszych bodźców. Traci zdolność zawierania zdrowych relacji, traktuje ludzi w sposób instrumentalny i bez empatii. Wytwarza fałszywy, zdegradowany obraz miłości dwojga ludzi. Dochodzi do dewiacji seksualnych, a pornografia i związana z nią masturbacja staje się jedynym znanym «lekarstwem» na problemy młodego człowieka. To uzależnienie, którego na pierwszy rzut oka nie widać”. Chrońmy dzieci i młodziė̇ przed pornografiq... Równie zastanawiająco brzmi tytuł wywiadu Pauliny Godlewskiej z KAI: Świecki seksuolog: pornografia może doprowadzić do końca Kościoła!, [wywiad z Bogdanem Stelmachem], aktualizacja 18.12.2017, [dostęp: 2018-06-20]. 
- uprzedmiotawianie i zohydzanie wizerunku człowieka. Dehumanizacja dokonuje się na różne sposoby, a przypomina znane $\mathrm{z}$ forów internetowych pozbawione wszelkich hamulców tzw. hejtowanie. Trudno bez odrazy przytaczać niektóre cytaty, np. obrazujące sposób wyrażania się Żulczykowych narratorów o dziewczynach, chcących dostać się na strony mediów plotkarskich. Zobaczmy jednak, jak po niewybrednych ich określeniach narrator mówi też o innych osobach:

Dwie z nich stoją obok nalanego producenta filmowego o wyglądzie czarnego charakteru z nieudanego filmu science fiction, faceta o twarzy podpułkownika KGB i posturze ogromnego, foliowego worka z wodą. (Śoś, s. 115)

Gdzie indziej znów, w kontekście lawiny wulgaryzmów, pojawia się aluzja do zachowań i niecenzuralnych (nomen omen pojęcie „niecenzuralny” w czasach liberalizmu przestało $\mathrm{w}$ wielu kręgach zupełnie obowiązywać) słów jakiejś prostytutki nazwanej jednoznacznie k...ą, że mówiła „nieśmiało, cicho, zupełnie nieautentycznie, jakby była na castingu do pornosa" (Śoś, s. 196). A oto jeszcze jeden przykład:

[...] podchodzi do niego jakiś koleżka. Jest mały, pokraczny, ma twarz ulepioną z mokrej ziemi, wygląda jak brzydkie dziecko z Hydrozagadki; ta twarz całodobowo pyta świat, o co w ogóle w nim chodzi i dlaczego powietrze jest przezroczyste. Mały, zgolony łeb mieści trochę g... a i dziesięć wyrazów po polsku. To mu wystarcza, by się poruszać i żreć. (Śoś, s. 245; wykropkowanie moje - D.K.)

W dalszej części niniejszego studium autorka pragnie wykazać, że bombardowanie umysłu czytelnika nie tylko rozmaitymi wulgaryzmami, obscenicznym obrazowaniem, a także owymi deprecjonującymi określeniami osoby ludzkiej, niezależnie od tego, jakim by ona nie była, wpływa destrukcyjnie na postrzeganie świata pozaliterackiego i zachowania interpersonalne. Mówi się nieraz o „wpadnięciu w złe towarzystwo”, twierdzi się też powszechnie, że „książka jest przyjacielem człowieka”. Jaki może być zatem wpływ owego „przyjaciela”, który jednocześnie przybliża zaciekawionego nim czytelnika prawie wyłącznie do niemoralnych środowisk, ignorujących podstawowe wartości, m.in. godność osoby ludzkiej? Owe turpistyczne, materialistyczne i reifikujące prezentacje wiążą się z kolejnym rysem omawianej tu prozy:

- niszczenie i podważanie wszelkich autorytetów - pokazywanie ludzkiego uniwersum jako w każdym calu skażonego złem. Wymowny np. jest pod tym względem jeden z głównych wątków Wzgórza psów - zbieranie przez Justynę materiału na temat gangu pedofilów: 
Mój informator, to paskudne słowo, informator, chłopak o imieniu Cyryl, którego zapraszaliśmy do domu, któremu dawaliśmy książki, jedzenie i ubrania - znaleziono go dwa miesiące temu na pasku w kuchni w mieszkaniu na Pradze. We krwi miał tablicę Mendelejewa. Koroner powiedział, że to wyglądało, jakby włamał się na zaplecze hurtowni dopalaczy i zjadł cały asortyment. Wśród ludzi, którzy do dwunastego roku życia zapłacili mu za seks, wymienił znanego polskiego reżysera, wieloletniego dyrektora różnych spółek skarbu państwa, byłego ministra rolnictwa i jednego z bardziej medialnie krewkich biskupów. Mówił, że tworzyli coś w rodzaju klubu. Że na swój użytek nazywali go Klubem Puchatka. Że chłopców i dziewczynek były dziesiątki. Z Gocławia, Tarchomina, Pragi Północ. Od ósmego do czternastego roku życia. (Wp, s. 115)

Nieprawdą byłoby twierdzić, że takie zjawiska w świecie realnym nie zachodzą. Ale nieprawdą jest też sądzić, że świat jest tylko zły. W czasach, w których poststrukturalistyczne uderzenie w tzw. logocentryzm (z autorytetem Logosu-Słowa i słowa objawionego, Boga, ojca, nauczyciela, kapłana itd.) dalej zda się obowiązywać i umacniać swoją pozycję, powieści i scenariusze Żulczyka w niczym pod tym względem nie odstają ${ }^{19}$. Znamienne dla światów przezeń przedstawionych jest również podważanie autorytetu rodziców przez prezentację ich zazwyczaj jedynie w negatywnym świetle. Matki (np. w powieściach dla młodzieży Zrób mi jakąś krzywdę i Zmorojewo) to zimne, despotyczne bizneswoman, od których ich nastoletnie córki uciekają z chłopakami. Natomiast ojcowie prawie wszędzie mają jakieś bardziej lub mniej ujawnione cechy psychopaty, hipokryty, sadysty, np. w serialu Belfer (do którego Żulczyk pisał scenariusz) i we Wzgórzu psów czy nieudacznika, np. w Instytucie. Bohaterka-narratorka ani razu nie mówi o nim „mąż”, ani razu nie wymienia jego imienia, ale określa go pogardliwie mianem „młody Lynch”, „ojciec Eli”, czyli biologiczny ojciec jej ukochanej córki. Nie możemy zaprzeczyć faktom, że wielu rodziców takich, jakich przedstawia Żulczyk, było i jest w rzeczywistości. Problem jednak polega na tym, że w tej twórczości wszyscy są skalani - nie ma już jakichś konstruktywnych, dobrych wzorców. Taki jednostronny obraz konfrontowany, co nie ulega wątpliwości, w percepcji odbiorców z realnym światem, powoduje w konsekwencji błędne koło, nakręca spiralę zła w społeczeństwie: pewne podpatrzone w społeczeństwie patologie zostają tu zwielokrotnione, w nienaturalnie zagęszczonych proporcjach nagromadzone i uczą, w obliczu braku jakichkolwiek aksjomatów i pozytywnych wzorców, jak zło dalej w życiu generować. Cechą badanej tu prozy nie jest bynajmniej opozycja zdegenerowanych „starych” i kierujących się wyższymi wartościami „młodych”, ale również:

${ }_{19} \mathrm{Na}$ temat postmodernistycznego antylogocentryzmu zob. więcej np. w: A. Szahaj, Co to jest postmodernizm?, „Ethos” Rok 9, 1996 nr 1-2 (33-34), s. 74 (całość artykułu: s. 63-78). Por.: A. Bronk SVD, Krajobraz postmodernistyczny, tamże, s. 79-100. 
- zohydzanie wizerunku samej młodzieży. Na kartach tych powieści są obecni w większości zdemoralizowani, hołdujący tzw. „,kulturze użycia”, żyjący w rozpuście, pijaństwie, narkomanii, lenistwie, dokonujący aktów wandalizmu, przeklinający nastolatkowie. „Kłamstwo powtórzone tysiąc razy staje się prawdą” - powiedział, jak wiadomo, przed laty niemiecki minister propagandy Joseph Goebbels. Dziś psychologia mówi o procesach, do których jeszcze pod koniec artykułu powrócimy - o przyzwyczajaniu umysłu - o torowaniu i nabywaniu skryptów. Wmawianie młodzieży poprzez odpowiednie, trzymające w napięciu i przykuwające uwagę powieści i filmy, że tylko w ten, niemoralny sposób może się zachowywać, że tak zachowują się też dorośli, że jest to normą, równa się z pozbawianiem jej motywacji do szlachetnego wysławiania się, do prawego życia. Tymczasem w ewokowaniu skandalicznych zachowań autor wykazuje wielką pomysłowość:

Tylko Aneta potrafiła zaciągnąć cię do multipleksu na jakąś komedię o przygodach upośledzonych ludzi z anglojęzycznych krajów, usiąść obok jakiegoś młodego małżeństwa i symulować orgazm przez połowę seansu. (RA, s. 186)

Albo:

[...] I słyszę pierwsze wybijane szyby. I widzę, jak grupa osób wpada do ogródka piwnego i przewraca stojący tam parasol prosto na bar. I biegniemy dalej, w kierunku zbudowanego pośrodku miasteczka studenckiego handlowego minicentrum (sic! - D.K.).

Ta fala biegnie. Ktokolwiek stoi jej na drodze, zostaje wciągnięty pod nią jak pod jakiś wsysacz materii.

- K...wa (wykropkowanie moje - D.K.), stary, czuję się jak w Bravehearcie. - Gnat uśmiecha się i wybija szybę w stojącym niedaleko samochodzie.

Widzę, jak dwóch kolesi wyrywa płytę chodnikową i rzuca nią w szybę wystawową salonu z telefonami. (RA, s. 351)

Oczywiście są setki jeszcze bardziej drastycznych obrazów potwierdzających tezę o konsekwentnie nieetycznym w tym powieściopisarstwie wizerunku współczesnej młodzieży, utwierdzającym zwłaszcza niedojrzałych odbiorców w fałszywym przekonaniu, że tylko tak może ona funkcjonować we współczesnym świecie. Narkomania i rozwiązłość seksualna prawie wszystkich młodocianych bohaterów Żulczyka, euforia Kasi z powieści dla młodzieży Zrób mi jakaśs krzywdę na myśl o spotkaniu $\mathrm{z}$ „prawdziwymi” aktorami porno, frustracja, ale i entuzjazm członków tytułowego Radia Armageddon z wyżej zacytowanego utworu $\mathrm{z}$ dokonywanego ulicznego rozboju są efektem i symptomem pewnej, u autora zabsolutyzowanej i zhiberbolizowanej dewaluacji wartości, dokonującego się również w rzeczywistości empirycznej przewartościowania, które najogólniej mówiąc sprowadza się do kolejnego zjawiska: 
- nazywanie zła dobrem, a dobra złem. Owo zło, kojarzone najczęściej z hołdowaniem najniższym pobudkom, staje się „złotym cielcem” współczesności. Autor konsekwentnie przekonuje, że w obliczu zdewastowanego sacrum i sanctum - niezależnie nawet od wpisywanej niekiedy autorskiej ironii - usankcjonowane zostały hedonistyczne wartości i pseudowartości. W poniższym cytacie dowodzi tego odpowiednia leksyka zapożyczona z pogranicza legend, baśni i religii, podkreślona pogrubioną czcionką:

Wśród wszystkich, którzy chodzą do naszej szkoły, istnieje pewien mit, powtarzana sobie od ucha do ucha legenda o świętym Graalu dorastających chłopaków - baśń o magicznym środku X: jeśli dosypiesz go dziewczynie do piwa, sprawia, że ogarnia ją przerażająca chęć pieprzenia się. To akurat sprzedał mi Gnat, pokazując swoją kolekcję dziesięciosekundowych zajawek filmów porno. Na pewno nie chodziło o tabletkę gwałtu [...]. Nie, chodziło o magiczny, cudowny środek, który sprawia, że każda, ale to każda dziewczyna, nawet najbardziej wypieszczona w Photoshopie aktorka porno, po zażyciu tego środka każe ci się pier...ić (wykr. moje - D.K.) przez trzy następne doby. Nic takiego oczywiście nie istnieje. Pigułki pieprzenia to zbiorowe pobożne życzenia, mit taki sam jak ludzie budzący się rano po imprezie z wyciętą nerką - ale wszyscy dorastający faceci wierzą w to tak mocno, jak twoja babcia wierzy w życie po śmierci. (RA, s. 84-85)

Wyeliminowanie z pola widzenia wartości wyższych, ośmieszenie ich i zastąpienie wartościami hedonistycznymi prowadzi do pewnej formy zezwierzęcenia, a w efekcie, jeśli nie do biologicznej, to na pewno duchowej śmierci: „Natura ludzka polega na nieustannym wysiłku przekraczania granic zwierzęcości tkwiącej w człowieku i wyrastania ponad nią człowieczeństwem i rolą człowieka jako twórcy wartości. Bez tej misji i bez tego wysiłku wyrastania ponad samego siebie człowiek zapada z powrotem i bez ratunku w swoją czystą zwierzęcość, która stanowi jego śmierć" - pisał sześćdziesiąt lat temu Roman Ingarden ${ }^{20}$.

Wszystkie powyższe mechanizmy wieloaspektowej destrukcji wartości wysokich, zastępowania kultury duchowej i systemu aksjonormatywnego propagandą „kultury użycia” zdają się być pokłosiem postmodernistycznego relatywizmu, kultu wolności od aksjologicznych zobowiązań, kryzysu Wielkich Narracji, o czym już pisał pół wieku temu Jean-François Lyotard ${ }^{21}$. Mentalność prezentowana na szeroką skalę w powieściach Żulczyka stanowi reperkusję wspomnianego już poststrukturalistycznego uderzenia w Logos i logocentryzm. Światopogląd ferowany w tej prozie przypomina też kult „wolności” i niezdrowej zabawy rodem $\mathrm{z}$ manifestów hipisowskich pokolenia ' 68 , z tym, że owiany

${ }^{20}$ R. Ingarden, Książeczka o człowieku, tł. A. Węgrzecki, Kraków 1972, s. 26.

${ }^{21}$ Zob. J.-F. Lyotard, Kondycja ponowoczesna. Raport o stanie wiedzy, przeł. M. Kowalska i J. Migasiński, Warszawa 1997, r. 10. „Delegitymizacja”, s. 111-119. Por. „Mała opowieść tłumacza” (Przedmowa), s. 5-16. 
smutkiem i poczuciem braku perspektyw. Toteż kolejnym rysem, w pewnym sensie niepokojącym, w obszernych narracjach Żulczyka jest:

- brak też jakiegoś bardziej pogłębionego odniesienia do świata Transcendencji. Człowiek okrojony jest do granic swojej - zresztą jednostronnie postrzeganej - cielesności; brak miejsca w takiej jego wizji dla duszy, brak troski o swoje i innych zbawienie. Nawet jeśli pojawiają się jakieś aluzje do Boga, do „rzeczy ostatecznych”, najczęściej są one znakiem zupełnego niezrozumienia tych spraw. Niekiedy mają też wymiar obrazoburczy; uderzają - jak np. pod płaszczykiem komizmu i żartu słownego zastosowanego w Radiu Armageddon - w świętość dla chrześcijan najwyższą: w Imię Jezus i w Boże Miłosierdzie (zob. RA, s. 95). Kwestia wymagałaby osobnego studium potwierdzającego tezę $\mathrm{o}$ antyboskim i antyeklezjalnym wymiarze tej prozy; tu jedynie zaznaczę, że nie wszyscy zapewne muszą podzielać zdanie o jej głębi. Andrzej Horubała np. pisze o „głębokiej rozpaczy [...] pokolenia”, zasygnowanej skomponowaniem Wzgórza psów wedle suplikacyjnych zwrotów „Od powietrza / Od głodu / Od ognia / Od wojny uchowaj nas, Panie”22. Ową „duchowość”, ale właśnie traktowaną à rebours, jako duchowość rozpaczy i zwątpienia, odsłania Żulczyk wielokrotnie, również przy temacie śmierci i refleksji nt. celowości rzekomego „wymyślenia” przez ludzi nieba czy też końca świata:

Wszystkie fantazje o apokalipsie wzięły się z tego, że człowiek nie chce być sam na sam ze śmiercią. Pragnie przeżyć ją zbiorowo, gromadnie, epicko, jak koncert na wielkim festiwalu muzycznym.

Tak w ogóle to najweselej dla wszystkich byłoby, gdyby na końcu świata śpiewał Bono. Niby nikt już nie lubi U2, ale koniec końców wszyscy się wzruszają, zwłaszcza przy tej piosence, co niby jest o Wałęsie. Więc zaśpiewałby Bono, wszyscy by się wzruszyli, a potem zdechli. (Wp, s. 16-17)

Z powyższym problemem wiąże się również - uchwycony przez pisarza, ale też konsekwentnie „roztaczany”:

- nihilizm i pustka ideowa naszych czasów. Trzeba jednak zauważyć, że taka proza generuje jeszcze bardziej ową pustkę bądź aksjologiczny chaos:

Ludzie kochają urojenia. Drżą od nich. Nazywają je sensami. Te „sensy” rozpuszczają się w powietrzu w momencie wypowiedzenia. Sama umiejętność ich sklecania jest pewnym fabrycznym uszkodzeniem. [...].

Wszystko, co robicie, wszystkie wasze codzienne czynności, wszystkie tworzone przez was konstrukcje są sklecane w jakimś niejasnym celu. Na samym końcu nitek, które dziergacie,

${ }^{22}$ Zob.: A. Horubała, Żulczyk rządzi!, „Do Rzeczy. Tygodnik Lisickiego”, nr 19/221, 8-14 maja 2017, s. 42 [całość: s. 42-44 - recenzja książki, Wzgórze psów]. 
próbujecie dostrzec jakieś światełko, jakiś refleks, cień czegoś. Wyraz Bóg nie jest już modny, a wy nie wymyśleliście jeszcze lepszego. Język tańczy dookoła tego światełka. Iluzja nawija się na iluzję. Mimo to, gdy o nich myślicie, jest wam cieplej. Wszystko sprowadza się do okoliczności. Na końcu dnia zawsze będziecie chronić tylko siebie. Gdy będziecie mieli okazję, aby zjeść drugiego robaka, zrobicie to zawsze. Szybko, ale ze smakiem. Nie ma czegoś takiego jak sens, jak bezinteresowny gest. Opowiadacie bajki. (Śoś, s. 456-457)

Zdanie wypowiedziane przez bohatera-narratora Ślepnąc od świateł jest symptomatyczne dla wielu innych protagonistów obecnych w tej prozie. Zwątpienie we wszystko, poczucie bezsensu, negacja wartości pociąga za sobą odpowiednie postawy życiowe, wybory oraz fascynacje, np. Hitlerem przez Jezusa (sic!) w Radiu Armageddon (zob. RA, s. 95) czy domorosłymi „gwiazdami porno” przez Kaśkę i Wiktora w „powieści dla młodzieży” (Zmjk, s. 106-130). Natura abhorret vacuum ('Natura nie znosi próżni') - miał powiedzieć niegdyś François Rabelais. Skoro imponderabilia nie istnieją, a aksjomaty uznawane są za puste, sensu poszukuje się tam, gdzie go tak naprawdę znaleźć nie można. To najczęściej obierana, zwłaszcza przez młodocianych bohaterów, droga. Wartości, jeśli się pojawiają, pozostają w nieustannym zagrożeniu:

Czasami dwoje ludzi myśli, że są ze sobą przyspawani. Miałaś podstawy, Nadzieja, bo po koncertach do Cypriana przychodziło coraz więcej anonimowych lolitek. Wszystkie wyglądały tak samo. Niektóre jedynie oblizywały usta, inne mówiły przez piętnaście minut o najlepszym koncercie, jaki widziały w życiu, inne bez przerwy się do niego uśmiechały. Gdy orientowały się, że to nie działa, machały mu przed twarzą kondomami. Przygważdżały go do ściany i wpychały mu język do ust. Oblewały go alkoholem. Łapały za krocze. Twój chłopak codziennie mógł żyć w filmie porno, ale przecież interesowałaś go wyłącznie ty. (RA, s. 186-187)

Z moralnego punktu widzenia niebezpieczne dla czytającej powieści Żulczyka młodzieży, są więc wzorce zachowania, jakie autor, w sposób skondensowany, przedstawia. Nie chodzi tutaj o te oczywiste, potępiane przez pisarza, jak oszustwa, nadużycia władzy, tortury, morderstwa itd., ale te, które stanowią styl życia jego bohaterów: rozpusta, oglądanie filmów pornograficznych, bezbożność, niesamowite lenistwo (zwłaszcza wśród młodzieży, która ani się nie uczy, ani nic dobrego nie robi dla innych): „Godzinami graliśmy na jego (Trupola - przyp. D.K.) komputerze w Duke Nukem, paliliśmy trawę i słuchaliśmy z rozklekotanego magnetofonu ścieżki dźwiękowej $Z$ Archiwum $X$ ” (Wp, s. 123). Powszechny bywa też handel, przemyt i zażywanie narkotyków. Proza Żulczyka może pod tym względem stanowić sui generis encyklopedię narkomanii i dealerstwa: nie tylko przecież w Ślepną od świateł pojawia się światek handlarzy środków substancji psychoaktywnych, padają najrozmaitsze nazwy owych środków. 
Niejednokrotnie przy tym - również w powieści „romantyczno-młodzieżowej”, a także $\mathrm{w}$ wywiadach przeprowadzanych $\mathrm{z}$ autorem - odnajdujemy sugestię, że zażywanie tych środków jest normalne, zwłaszcza w środowiskach uczniowskich i studenckich.

\section{Błędne koła - z perspektywy pedagogiki i teorii odbioru dzieła literackiego}

Po przedstawieniu wątpliwych pod względem aksjologicznym rysów tej prozy należałoby zapytać: jakie są przesłanki, by twierdzić, że ona nie tyle diagnozuje, co generuje patologiczne zachowania? Bo przecież nie można zamknąć oczu i twierdzić, że wszystkich wyżej omówionych zjawisk nie ma w społeczeństwie. Przede wszystkim więc należy oddać sprawiedliwość prawdzie i przyznać, że autor w pewnym sensie rzeczywiście diagnozuje społeczeństwo ${ }^{23}$.Z tym, że uogólnia, absolutyzuje, wszelkim przejawom życia społecznego imputując degrengoladę, prawie wszędzie widząc wynaturzenie, które w jego powieściach niemalże staje się obyczajową normą. Najlepszym dowodem na taką wizję świata i aksjologiczny relatywizm są słowa ze Wzgórza psów: „Gdyby to był dobry świat, to może zrobilibyśmy coś złego. Ale to nie jest dobry świat. - Grzesiek pokręcił głową" (Wp, s. 825-826). W świecie permanentnie opanowanym przez zło - wedle fałszywej wykładni rzeczywistości - pojedyncze jego akty niczym się już nie wyróżniają, nie mogą być stygmatyzowane jako szkodliwe. Drugi wniosek sprowadza się również do czegoś, co powinno niepokoić: autor nie tylko diagnozuje patologiczne zachowania w społeczeństwie, ale przez ich szczegółowe odtwarzanie i kondensację utrwala i generuje. Zresztą pomysłowość w wymyślaniu ordynarnych wyrażeń, perwersyjnych obrazów i ciągów skojarzeń (nieznoszących u niego przemilczenia i dyskrecji) nie zna granic. Sam autor nie wykazuje ani wstrzemięźliwości, ani autorskiego dystansu: otaczająca nas zewsząd i postępująca w społeczeństwie np. wulgaryzacja języka, jest nie tyle stwierdzana, ile pozostaje w stałym, nagminnym użyciu samego autora. W ten sposób Żulczyk, mocą swego pisarskiego autorytetu (choć nie tylko na tej drodze), daje niejako przyzwolenie i instrukcję, by tak dalej kaleczyć ludzką mowę i rodzimy, naro-

${ }^{23}$ Proza Żulczyka świetnie się nadaje do tzw. badań kulturowych. Najrozmaitsze nazwy piwa i napojów energetyzujących, narkotyków i leków odurzających, psychotropów, dopalaczy, różne marki i ich białoruskie, rosyjskie, ukraińskie „podróby” papierosów, nazwy win i piw; soliści i zespoły rockowe, metalowe, techno i ich utwory; kabarety i ich festiwale; konsole, play stations, filmiki na smartfonach i gry komputerowe; Facebook i inne portale; Netfiks i stacja MTV; plakaty zespołów, solistów i gwiazd filmowych; nowomowa $\mathrm{z}$ kombinacjami przekleństw i wulgaryzmów, których niegdyś nie znali nawet najwięksi deprawatorzy - wszystko to tworzy mozaikę składającą się na rzekomo tylko w ten sposób i za wszelką cenę wybijający się z nudy i nostalgii smutny świat XXI. 
dowy język. Jest to jeden z najbardziej ewidentnych dylematów aksjologicznych tej prozy. Problemem w rzeczywistości empirycznej jest nie tylko wspomniana wulgaryzacja i ubożenie języka, lecz również ignorancja, niezauważanie problemu, zo b o j ę t $\mathbf{n}$ i e n i e. Takim niestety tendencjom służy proza nie tylko Żulczyka, ale wielu innych współczesnych pisarzy. Zakładając, że obiektywnie jest to poważny problem, trzeba się zastanowić, czy literatura rzeczywiście ma taką moc, by uczyć złych zachowań, niewłaściwych, gorszących sposobów wyrażania się, wulgarnego odnoszenia się do siebie samych i do innych ludzi. Głosy są w tej kwestii podzielone. Pisząc więc ten artykuł, zmagam się w rozmowach nie tylko z oponentami na temat problemu "zgorszenia”, „deprawacji” dokonywanej przez tego pokroju twórczość; zmagam się zwłaszcza z poglądem, że nic nie może zdemoralizować człowieka, jeśli on na to zdemoralizowanie nie przyzwala, o czym zresztą, w pewnym sensie, mówił sam Chrystus, który jednocześnie pouczał o gorszeniu „maluczkich” ${ }^{24}$. W tym miejscu należałoby jednak powołać się na naukowe stwierdzenia profesora dydaktyki języka polskiego Leszka Jazownika oraz na teorie behawioralne, nie wyłączając koncepcji psychologiczne dotyczące tzw. skryptów i tzw. modelowania.

Otóż Leszek Jazownik w erudycyjnej książce Wyzwolić moc lektury solidaryzuje się z pewną grupą badaczy, którzy uważają, że „dzieła literackie są «nośnikami» pewnych idei i wartości”. Są to „«idee ogólne» (filozoficzne, egzystencjalne itp.) oraz «wartości najwyższe» (metafizyczne, uniwersalne itd.)”. Tak pojmowane idee i wartości badacz charakteryzuje jako „światopoglądowe”25. Zauważa też, że właśnie wartości wyższe i najwyższe są współcześnie ignorowane bądź spychane na margines:

${ }^{24}$ W Biblii Wujka (Pismo święte Starego i Nowego Testamentu, w przekładzie polskim W.O. Jakuba Wujka S.J., tekst poprawili oraz wstępami i krótkim komentarzem opatrzyli: ks. S. Styś S.J., ks. W. Lohn S.J., Kraków 1962) interesujący nas werset brzmi następująco: „Nie ma żadnej rzeczy zewnątrz człowieka, która by, wchodząc weń, splugawić go mogła; lecz rzeczy, które wychodzą z człowieka, te są, które plamią człowieka" (Mk 7,15). W innych miejscach Nowego Testamentu czytamy jednak o zgorszeniach „maluczkich” (por. np.: Mk 9,42). O zgorszonych i zdemoralizowanych Jezus mówił w dalszej części kazania: „z wnętrza, z serca człowieka pochodzą myśli złe, cudzołóstwa, porubstwa, zabójstwa, kradzieże, łakomstwa, złości, zdrada, bezwstyd, złe spojrzenia, bluźnierstwa, pycha, głupota. Wszystko to złe z zewnątrz pochodzi i plami człowieka" (Mk 7, 21-23).

${ }^{25}$ L. Jazownik, Wyzwolić moc lektury. Aksjologiczno-dydaktyczny sens dzieła literackiego, Zielona Góra 2004, s. 14. Autor, opowiadając się za promowaniem świata wartości, zwłaszcza w szkole, reaktywuje w swojej książce m. in. pojęcie światopoglądu (tezę o „poglądzie na świat” czerpie z dzieł najwybitniejszego dydaktyka XX-lecia międzywojennego - Kazimierza Wóycickiego i jego książki Rozbiór literacki w szkole. Podręcznik dla nauczycieli, Warszawa 1921. Ale termin ten, według badacza „może poszczycić się wyjątkowo szacownym pochodzeniem: wprowadzony przez Fryderyka E. Schleiermachera, upowszechniony został przez Wilhelma Diltheya" (tamże, przypis 12, s. 13). Badacz stoi na stanowisku, że literatury właśnie po to się w szkole uczy, aby propagować wartości. 
Jednym z najbardziej symptomatycznych rysów epoki ponowoczesnej i opiewającej ją myśli postmodernistycznej jest swoista dewaluacja refleksji "metafizycznej”. Charakterystyczne dla owej refleksji pojęcia, takie jak „,rzeczywistość”, „absolut”, „człowiek” czy "prawda", zostały całkowicie zdezawuowane ${ }^{26}$.

Właśnie taka dewaluacja zachodzi w prozie Żulczyka. Najbardziej zdeprecjonowany jest w niej język, a poprzez język, rozumiany jako nośnik znaczeń, niszczone są tam wszystkie wyższe i najwyższe wartości. To samo zresztą dzieje się, choć nie w takim natężeniu, w świecie nas otaczającym. Zapewne jest to wynik różnych postmodernistycznych filozofii, ale także - co zauważa zielonogórski badacz - istnienia tzw. antypedagogiki, znanej w Polsce przede wszystkim za pośrednictwem prac Hubertusa von Schoenebecka, a „głoszącej potrzebę zastąpienia oddziaływań wychowawczych (traktowanych jako przejaw bezprawnego i wspierającego się na przemocy narzucania młodemu pokoleniu norm i reguł uznawanych w świecie dorosłych) dyskretnym wspieraniem spontanicznego, niczym nieskrępowanego samorozwoju dziecka; wspieraniem - dodajmy - realizowanym przy poszanowaniu przysługującego wychowankowi prawa do samostanowienia o własnej edukacji”27. Zauważmy, że idzie to w parze $\mathrm{z}$ afirmacją we współczesnych społeczeństwach takich - zresztą źle pojętych postaw i wartości, jak „wolność”, „spontaniczność” czy krytykowane w 1987 r. przez konserwatywnego myśliciela Allana Blooma w The Closing of the American Mind: „autentyczność”, egotyzm wyrażający się w samorealizacji i aksjologiczny relatywizm pozwalający każdemu mieć własne zdanie również na kwestie moralne. Chociaż komentujący myśl Blooma neo-arystotelik Charles Taylor w swojej sławnej Etyce autentyczności nie w pełni zgadza się z pesymistyczną wizją autora Umysłu zamkniętego, to jednak również i on, doceniając współczesny indywidualizm, przekreślający niejednokrotnie prawa drugiego, altruizm i postawy obywatelskie, dostrzega zasadniczo „trzy bolączki współczesności”:

Pierwsze zagrożenie dotyczy tego, co możemy nazwać utratą sensu albo zanikiem horyzontów moralnych. Drugie - wyrugowania celów przez panoszący się rozum instrumentalny. Trzecie - utrata wolności ${ }^{28}$.

${ }^{26}$ Tamże, s. 41. Jazownik zgadza się w tym aspekcie z opinią Anny Grzegorczyk, która pisała: „Najmodniejsze i najbardziej liczące się trendy w myśli humanistycznej - pisze Anna Grzegorczyk prawie że jednogłośnie ujawniają kryzys, jeżeli nie katastrofę podstawowych kategorii filozoficznych. Kryzys jest tak głęboki, że już tylko ironia może je wydobyć, włożyć pod pióro filozofa i określić sposób posługiwania się nimi w jego tekście. Bez ironicznego dystansu nie wypada nawet głośno mówić o nich i mówić nimi”. Taż, Anioł po katastrofie, Warszawa 1995, s. 9.

${ }^{27}$ L. Jazownik, Wyzwolić moc..., s. 44-45.

${ }^{28}$ Ch. Taylor, Etyka autentyczności, przekład A. Pawelec, Kraków 1996, s. 16. Krytykę poglądów Allana Blooma autor przeprowadza tam na s. 18-26. 
I on dostrzega, że współczesny, jakże różny od romantycznego, indywidualizm wiąże się $z$ hedonizmem, egotyzmem, narcyzmem, zabijaniem norm i autorytetów. Życie przez to ulega spłaszczeniu. Są to skutki „społeczeństwa permisywnego”, wyczynów „pokolenia egoistów” [me generation] czy eksplozji "narcyzmu"29.

Ich wyznawcami są nie tylko Żulczykowi bohaterowie, ale - jeśli wolno w tym miejscu uprawiać biografizm ${ }^{30}$ - również on sam. Przypomnijmy choćby tłumaczone prawem do autentyczności, usprawiedliwianie (de facto tragikomiczne) ogromu wulgaryzmów w jego prozie. Tak samo postępuje dziś młodzież, bezrefleksyjnie wplatająca ordynarne słowa do swoich wypowiedzi: upomniana, w najlepszym przypadku, tłumaczy się sloganem ,jestem autentyczny/autentyczna”. I tu tkwi problem: w ten sposób przyznają, co rzekomo stanowi ich istotę, co jest prawdą o nich. Autentyczny bowiem z greckiego authenticós 'gwarantowany' - znaczy 'prawdziwy, rzeczywisty, oryginalny, niepodrobiony, wiarygodny' ${ }^{31}$. Zapewne tym wszystkim apologetom rozwiązłości w języku przyświeca myśl, że brak skrępowania regułami kulturalnego wyrażania się, zwłaszcza w miejscach publicznych (nota bene twórczość literacka też jest sui generis domeną publiczną) daje wolność, a zatem gwarantuje szczęście. Czy ubóstwo, a jak u Żulczyka nie tyle ubóstwo, ile degradacja języka może generować szczęście? Jazownik rozwija i udowadnia myśl, że światopogląd związany ze światem wyższych wartości i idei potrzebny jest dla zdrowia (szczególnie zdrowia psychicznego), tym samym dla życia i dla szczęścia ${ }^{32}$. Prowadząc polemikę z fenomenologami, zgadza się tylko z tą ich tezą, że „korelatem przedmiotowym tego, co zwykło się nazywać emocjami, są wartości ${ }^{33}$. Różne reakcje na wydarzenia i postawy fikcyjnych bohaterów (na akty i aktantów - jak by mówili jeszcze strukturaliści) są reakcjami na nic innego, jak na światopogląd i uniwersum wartości czy antywartości. Reakcje te - co ważne - przebiegają często nieświadomie:

[...] na ogół jednostki nie werbalizują, a nawet nie uświadamiają sobie w pełni treści przeświadczeń światopoglądowych, z których perspektywy dokonują wartościowań.

${ }^{29}$ Por. tamże, s. 11.

30 Zob.: M. Gołaszewska, Kim jest artysta?, Warszawa 1986, s. 10 oraz cały rozdział: „Związek procesu twórczego artysty z osobowością twórczą", s. 21-29.

${ }^{31}$ W. Kopaliński, Słownik wyrazów obcych i zwrotów obcojęzycznych, Warszawa 1980, hasło: autentyczny, s. 99.

32 Zob. L. Jazownik, Wyzwolić moc..., s. 54-61.

33 Tamże, s. 102. Wcześniej autor przytacza różne stanowiska fenomenologów, spośród których to opinii szczególnie dla nas istotne powinny wydawać się dwie: „2. Korelatem przedmiotowym przeżyć emocjonalnych (uczuć) są wartości (Meinong, Husserl, Scheler, Hartman)” oraz: „4. Wartości wychwytywane w przeżyciach emocjonalnych tworzą układ hierarchiczny; przy czym wartości znajdujące się na szczycie tego układu mają charakter absolutny, niezrelatywizowany (Meinong, Husserl, Scheler)”. Tamże, s. 100. 
Nierzadko też nie zdają sobie sprawy z przekształceń, jakim przeświadczenia te podlegają. (podkr. moje - D.K.) Natomiast emocje są nad wyraz łatwo dostępne w aktach introspekcji. Dlatego też pojawia się w tej sytuacji dość naturalna skłonność do tego, by uznawać, że to właśnie emocje, nie zaś przekonania światopoglądowe, są głównym „polem” oddziaływań dzieł literackich. Nie dostrzega się więc, że emocje [...] są zjawiskiem zupełnie wtórnym ${ }^{34}$.

Wbrew liberalnym trendom występującym we współczesnym świecie badacz podpowiada, że literatura powinna służyć promowaniu wartości. Bowiem literatura (kultura) wpływa - powtórzmy - na światopogląd, a ten na poczucie sensu czy bezsensu, szczęścia lub nieszczęścia, zdrowia bądź choroby psychicznej. Kiedy on uważa, że kultura reguluje światopogląd, a światopogląd reguluje odbiór kultury, my musimy zauważyć jeszcze inne sprzężenie zwrotne: społeczeństwo podpowiada pisarzowi wulgarny język, ten je asymiluje, ale i uczy własnych neo-wulgaryzmów; społeczeństwo zainteresowane jego pisarstwem daje przyzwolenie, by tak - np. w sposób wulgarny - on pisał; pisarz z kolei daje, tworząc kolejne utwory utrzymane w tym stylu, przyzwolenie, by tak się zachowywać, zwłaszcza takim językiem mówić. Są to w istocie błędne koła. Lektura i odbiór innych dzieł kultury może kształtować osobowość człowieka, może budować, ale może i niszczyć psychikę, może też przekształcać (defo)rmować wizję istoty ludzkiej i jej miejsca w świecie. Dotyczy to w równym stopniu interesującej nas tu kultury języka. Tak więc fałszywa kultura, anty-kultura wyrastająca $\mathrm{z}$ niezgodnego $\mathrm{z}$ etyką, swobodnie uformowanego światopoglądu może także rozregulować światopoglądy odbiorców. Wtedy też - co zdaje się, że obserwujemy obecnie - następuje efekt domina bądź błędnego koła: autorytety wprowadzają słownictwo niecenzuralne, użytkownicy języka dostają dodatkowe przyzwolenie na jego używanie; kolejne autorytety pod pretekstem podpatrywania / diagnozowania / mówienia prawdy o świecie je propagują, a kolejni odbiorcy wprowadzają tym bardziej w obieg. Itd., itd.

Według hermeneutów, również według cytowanego tu Jazownika literatura jest po to $\mathrm{m}$. in., by kształtować w czytelniku świat wartości. Jeśli lansuje antywartości, ich wzór zapada w pamięci czytelników. Jeśli jest przesycona wulgaryzmami i obscenicznymi obrazami, one również kształtują, a de facto deformują język odbiorcy oraz jego wizję rzeczywistości pozaliterackiej. Autorka niniejszej pracy ośmiela się postawić tezę, że nawet jednostce stawiającej wolicjonalnie opór przeciw złu ukrytemu w danej twórczości, zwłaszcza w liczącej w sumie kilka tysięcy stron prozie epatującej wulgaryzmami, całe nagromadzenie brudu w tego typu twórczości wchodzi „bocznymi kanałami” i osadza się - po Freudowsku rzecz ujmując - w świadomości, podświadomości i nieświadomości (z perspektywy wiary boczne kanały przypominają drzwi, jakimi przychodzi

34 Tamże, s. 104-105. 
szatan wraz ze złymi duchami do pustego domu, czyli duszy ludzkiej pozbawionej światła Ducha Świętego - por.: Mt 12,43). W ten sposób autorka artykuł pragnie powiedzieć coś więcej, niż autor książki Wyzwolić moc lektury. Nawet jeśli reakcją na zło, na antywartości tkwiące we współczesnej prozie polskiej (powieści Żulczyka są jedynie synekdochą o wiele szerszego zjawiska) jest wstręt, odraza, zgorszenie, smutek, poczucie zagubienia, gniew itd., to treści i sposób ich artykulacji i tak zapadają w jego pamięci. Oczywiście ten sam - tyle że przez aprobatę wzmocniony - proces zachodzi u tych, którzy z satysfakcją i przyjemnością oddają się takiej lekturze.

\section{Demoralizacja? Spojrzenie z perspektywy psychologii}

Najbardziej przekonujących uzasadnień psychologicznych, że jednak to wszystko, z czym spotykamy się, również w trakcie lektury, zapada w świadomości i podświadomości, dostarczają psychoanaliza (zwłaszcza teoria psychodynamiczna Zygmunta Freuda odnosząca się do treści ukrytych w nieświadomości) oraz behawioryzm. Ten ostatni, uogólniając, głosi tezę, że uczenie się zachowań odbywa się przez wzorce. Proces powstawania treści nieświadomych w ujęciu psychodynamicznym oparty jest na mechanizmach emocjonalnych. W ujęciu behawiorystycznym (a szczególnie w jego rozwinięciu zwanym teorią społecznego uczenia się) i podejściu poznawczo-behawioralnym przyjmuje się, że nabywanie postaw czy wzorów myślenia lub postępowania zachodzi poprzez proces uczenia się $^{35}$. W procesie tym niebagatelną rolę odgrywa oczywiście środowisko, o czym przekonuje nurt $\mathrm{w}$ behawioryzmie zwany enwironmentalizmem, a rozumiany jako „kształtowanie środowiskowe” ${ }^{\text {”6 }}$. Można byłoby powiedzieć, że pisarza (tu konkretnie: Jakuba Żulczyka) bez wątpienia ukształtowały jakieś czynniki środowiskowe, nas jednak interesuje udowodnienie tezy, że jego z kolei twórczość kształtuje, a raczej deformuje osobowość czytelników. Bardzo pomocne wydaje się zdanie klasyka behawioryzmu - Burrhusa F. Skinnera: „W praktyce wszystkie [...] sposoby zmieniania ludzkiej psychiki sprowadzają się do manipulowania

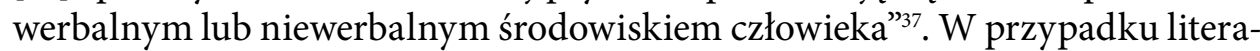
tury jest to manipulacja werbalna; przemoc symboliczna, o której już wcześniej

${ }_{35}$ Zob.: C. Tavris, C. Wade, Psychologia. Podejścia oraz koncepcje, przekł. J. Gilewicz, Warszawa 1999. Zob. zwłaszcza części: III. „Podejście teorii uczenia” oraz IV. „Podejście poznawcze”.

${ }^{36}$ Zob.: S. Koch, Psychologia wobec przejawiajacych się koncepcji jednolitej wiedzy, thumaczenie R. Stachowski, w: Behawioryzm i fenomenologia, redakcja T.W. Wann, (różni tłumacze), Kraków 2002, s. 11-62. Wśród różnych prądów pojawiających się w dziejach behawioryzmu Koch wymienia tam enwironmentalizm rozumiany jako „kształtowanie” środowiskowe - tamże, s. 20.

${ }^{37}$ B. F. Skinner, Pół wieku behawioryzmu, tłumaczenie J. Siuta, [w:] Behawioryzm i fenomenologia..., s. 115 (całość artykułu: s. 99-135). 
była mowa. W książce Poza wolnościa i godnościa w rozdziale 5. „Alternatywa kary" Skinner wprowadza pojęcie majeutyki:

\begin{abstract}
Metody kształtowania zachowań bez ujawniania nadzoru zawarł Sokrates w metaforze o położnej: ktoś pomaga drugiemu człowiekowi w narodzinach zachowania (podkr. moje - DK.). [...] Sokrates wprowadził do nauczania metodę położniczą, czyli majeutyczną. Dowodził on, że można tak pokierować człowiekiem, że młody niewykształcony niewolnik wyprowadzi twierdzenie Pitagorasa. [...] Ważną korzyścią jest to, że „położnik” unika odpowiedzialności. Akuszerka nie jest winna temu, że dziecko urodziło się martwe lub zniekształcone, a zatem nauczyciel, posługujący się majeutyką, nie jest winien, że student oblał egzamin, nie jest winien psychoterapeuta, że pacjent wybrnął z kłopotów a przywódca mistycznego kierunku religijnego nie ponosi winy, gdy jego uczniowie źle się prowadzą ${ }^{38}$.
\end{abstract}

Wydaje się, że współcześni deprawatorzy, zdobywający skądinąd nagrody i uznanie (co dla czytelników jest dodatkowym argumentem, tj. wzmocnieniem, by sięgać po ich utwory) stosują majeutykę - sterują zachowaniami, generują i utwierdzają nieetyczne nawyki, nie ponosząc za to odpowiedzialności. Zresztą na zarzut deprawacji odpowiedzieliby oni, że literatura, podobnie jak teatr, film itd. nie mają spełniać żadnej misji, a tym bardziej misji wychowawczej. Zapominają przy tym, że owe dziedziny należą do kultury, czyli tego, co pierwotnie wiązało się $\mathrm{z}$ uprawą, ale i $\mathrm{z}$ wychowaniem (śrdw. łac. cultivare 'uprawiać' $\mathrm{i}$ ang. culturist 'zwolennik jakiejś metody kształcenia umysłu albo ciała', [...] z łac. cultura 'uprawa; kształcenie' od cultus p.p. od colere 'uprawiać; pielęgnować; zamieszkiwać' ${ }^{39}$. Zmieniły się paradygmaty tego, co kulturalne, zmieniły się też

${ }^{38}$ B. F. Skinner, Poza wolnościa i godnościa, przełożył W. Szelenberger, przedmową opatrzył J. Szacki, Warszawa 1978, s. 104-106. Skinner jest psychologiem, uzależniającym wszystko, każde zachowanie, od wzmocnień i kar. W systemach wartości, we wszelkich regulacjach norm widzi manipulację i presję; człowieka postrzega instrumentalnie jako bezwolne narzędzie w rękach instancji "projektujących kulturę" i sprawujących nad jednostką czy społeczeństwem władzę i kontrolę. Wartości są według niego relatywne, ich dodatniość lub ujemność zależą od kontekstu. Nie ma wartości istniejących obiektywnie. Z takimi tezami trudno się zgodzić. Nas jednak interesuje całkiem co innego: uczenie zachowań przez obserwację, doświadczenie (również doświadczenie czytelnicze).

${ }^{39}$ W. Kopaliński, Słownik wyrazów obcych i zwrotów obcojęzycznych..., hasło: kult, s. 542. Szczególnie na wychowawczą rolę kultury zwracał uwagę Jan Paweł II. Pisze o tym m. in. Anna Koszewska w artykule Koncepcja antropologiczna zawarta w rozprawie Osoba i czyn Karola Wojtyly jako podstawa refleksji o twórczości artystycznej, [w:] Kultura nie tylko literacka. W kręgu myśli Karola Wojtyły-Jana Pawła II, część 2, „Scripta Humana” t. 10, redakcja naukowa D. Kulczycka i A. Seul, Zielona 2018, s. 41-52. Psycholog Marzanna Farnicka, referując poglądy Marii Tyszkowej, konstatuje, że „rozumie ona kulturę jako przejaw całości środowiska życiowego, przekształcający jego elementy, modelujący środowisko społeczne oraz tworzący ludzki świat wyobrażeń i wartości upośredniających kontakt jednostki z otoczeniem. W węższym znaczeniu przywołana autorka rozumie kulturę jako całokształt zachowań i wytworów działalności techniczno-użytkowej oraz 
oczekiwania ludzi względem kultury. To fakt. Zmienia się też hierarchia wartości. Jeśli tacy pisarze, jak Jakub Żulczyk (ale też Dorota Masłowska, Szczepan Twardoch, Sylwia Chutnik, Manuela Gretkowska ${ }^{40} \mathrm{i}$ wielu in.) utrwalają w swojej prozie antywartości, należy się niepokoić, że idzie to właśnie w takim kierunku, gdyż jak pisze uznany polski psycholog społeczny Tadeusz Mądrzycki -

Jednostka, tworząc koncepcję siebie i swój plan życia, opiera się w mniejszym lub większym stopniu na wartościach społecznych, stanowiących podstawowy, wręcz osiowy ich składnik. Znając kulturowy układ odniesienia, może [...] przyjmować od społeczeństwa pewne wartości, a odrzucać inne, może także modyfikować je lub włączać do nich sądy oparte na doświadczeniu indywidualnym (Mądrzycki 1977) ${ }^{41}$.

Ponadto we współczesnej psychologii można znaleźć odniesienia do wartości promowanych w kulturze:
[...] wartości są przejawem środowiska życiowego jednostki i jego budulcem wykorzystywa- nym do interpretacji doświadczeń życiowych oraz tworzenia oczekiwań wobec przyszłości [...]. Wartości odgrywają także rolę „strażników” kulturowych wzorów zachowań. Pełnią one taką funkcję ze względu na to, że ulegają zmianie stosunkowo wolniej i trudniej niż inne składniki kultury [...]. Od ich stabilności zależy więc stałość kultury i powtarzalność rozwoju jednostek oraz grup ją tworzących ${ }^{42}$.

Jaką mamy pewność, że język, obrazowanie właściwe omawianej tu prozie konstytuują wyobraźnię jej czytelników i wpływają negatywnie na ich sposób myślenia, artykułowania myśli, traktowania siebie i innych ludzi? Odpowiedź znajdziemy w innej książce reprezentującej klasykę behawioryzmu, a mianowicie w pracy Umyst, osobowość i społeczeństwo George’a H. Meada, piszącego o naśladownictwie cudzych głosów:

\footnotetext{
symbolicznej, nastawionych na interpretację świata i przeżywanie wartości. W obu ujęciach podkreśla znaczenie wartości, które należą zarówno do obszaru kultury (ujęcie ogólne), jak i są «narzędziem» jej odbioru [...]". M. Farnicka, Przemiany realizacji zadań rozwojowych. Ewolucja czy rewolucja?, Zielona Góra 2011, s. 29.

${ }^{40}$ Oczywiście ci pisarze różnią się od siebie i warsztatem, i zmysłem obserwacji, spektrum tematycznym i treścią przekazu. Na przykład „dyżurnej skandalistki polskiej literatury” Gretkowskiej (określenia Andrzeja Horubały; zob. tenże, Cienka zupka Gretkowskiej, „Do Rzeczy. Tygodnik Lisickiego", nr 35/237, 28 sierpnia - 3 września 2017, s. 41 [całość: s. 40-42]) nie można w żaden sposób porównywać do również skandalizującego, ale mającego więcej do powiedzenia, Żulczyka.

${ }^{41}$ T. Mądrzycki, Psychologiczne prawidłowości kształtowania się postaw, Warszawa 1977. Cyt. za: M. Farnicka, Przemiany realizacji zadań rozwojowych. Ewolucja czy rewolucja?, s. 33.

42 Tamże, s. 33.
} 
Wydaje się jednak, że wśród ludzi występuje tendencja do naśladowania, a szczególnie do odtwarzania gestów wokalnych. Tę ostatnią tendencję odnajdujemy także wśród ptaków. Jeżeli ktoś zamieszka w miejscowości, w której mówi się jakimś szczególnym dialektem, i pozostanie tam przez pewien czas, to zauważy, że mówi tym dialektem, chociaż może nie chce tego robić. Najprostszym sposobem wytłumaczenia tego faktu jest stwierdzenie, że ten ktoś nieświadomie imituje. Jest to prawdziwe także w odniesieniu do różnych innych zwyczajów ${ }^{43}$.

Zgodne z moją tezą są również wyniki badań współczesnej psychologii, zwłaszcza psychologii agresji. Ważne miejsce w owym dyskursie zajmuje problemat wspomnianych już skryptów:

Skrypty definiowane są jako struktury wiedzy obejmujące sekwencje wydarzeń doświadczonych przez podmiot wraz z kontekstem życia [...]. Doświadczenie zdobywane jest w sposób wymagający większego lub mniejszego zaangażowania (psychicznego i/lub fizycznego) w czynności i działania, w różnym stopniu pochłaniający czas i energię podmiotu. W tym pierwszym przypadku mówimy, że ma charakter bezpośredni, a w drugim - pośredni (np. zdobywane poprzez media, Internet). Wszelkie zachowania społeczne, tak prospołeczne, jak i agresywne, podlegają regulacji przez skrypty ukształtowane na bazie doświadczeń (zasoby behawioralne) zgromadzonych we wczesnej socjalizacji [...]. Traktowane są jako reprezentacje poznawcze różnych sytuacji, w tym ich cech krytycznych, oczekiwań wobec innych uczestników życia społecznego i możliwych konsekwencji różnych zachowań podmiotu i innych osób ${ }^{44}$.

Owe struktury wiedzy, najczęściej zdobyte w doświadczeniu życiowym, wpisują się na stałe w umyśle osoby. Zbudowane we wczesnym dzieciństwie, praktycznie są niemożliwe do zmodyfikowania ${ }^{45}$, również nabywane w młodości bezpowrotnie utrwalają się w pamięci. Czyli inaczej mówiąc: są to pewne klisze myślenia, mówienia i zachowań, które świadomie, a częściej: bezwiednie się kopiuje. Mózg przyzwyczaja się do pewnych obrazów, słów, pojęć, by później korzystać z pamięci, nieraz zresztą w nieoczekiwany sposób. Nawet jeśli podczas lub po lekturze dzieł „nafaszerowanych” wulgaryzmami i obscenicznymi aso-

${ }^{43}$ G.H. Mead, Umyst, osobowość i społeczeństwo, przełożyła Z. Wolińska, wstępem opatrzyła A. Kłoskowska, Warszawa 1975, rozdział 8. „Naśladownictwo i powstanie języka”, s. 85. W następnym rozdziale - 9. „Gest wokalny i symbol znaczący” (s. 88) autor powtarza jeszcze raz tę myśl: „Pojęcie naśladownictwa jest szeroko stosowane w odniesieniu do gestu wokalnego. Wydaje się, że pewne organizmy przejawiają tendencję do odtwarzania słyszalnych dźwięków. Ilustracją są tu istoty ludzkie oraz mówiące ptaki”.

${ }^{44}$ M. Farnicka, H. Liberska, D. Niewiedział, Psychologia agresji, wybrane problemy, rozdział: 3.4. „Agresywne skrypty a przetwarzanie informacji społecznych”, Warszawa 2016, 62-63.

${ }^{45}$ Por. tamże, s. 63. 
cjacjami pojawia się ich „odrzucenie” i „wstręt”, to nie znaczy, że nie doszło już do zinterioryzowania niepożądanych słów, postaw, wyrażeń, zachowań. Może się ono ujawnić w normalnych, ale także w ekstremalnych sytuacjach człowieka, np. w stresie, w popłochu, w cierpieniu, w obliczu niebezpieczeństwa, wobec zbliżającej się śmierci itd.

Nabywanie skryptów rozgrywa się na poziomie neurologicznym i zjawisko to wykorzystują specjaliści od reklamy, politycy, ideolodzy, w końcu - reżyserzy, autorzy gier komputerowych ${ }^{46}$, pisarze, przemycający w określonym języku i za pomocą określonych obrazów pewną wizję świata. Taki rodzaj „perswazji”, przyzwyczajanie mózgu do pewnych słów, obrazów, wyobrażeń nazywa się też torowaniem umysłu (ang. priming) ${ }^{47}$. Jeśli więc młodzież w okresie kulturotwórczym związanym według Karla Lorenza $\mathrm{z}$ „rozwojem myślenia pojęciowego” czyta pełną wulgaryzmów prozę, a ponadto - na zasadzie wzmocnienia - słyszy dookoła od rodziców, rówieśników, rodzeństwa, z radia, z Internetu, z telewizji wulgarny język - takie słownictwo i sposób wyrażania się utrwala. Doniosłe znaczenie ma przy tym rola autorytetów - jeśli ulubieni bohaterowie literaccy czy filmowi posługują się stylem nielicującym przecież z godnością człowieka, jeśli mówią tak aktorzy (również poza planem filmowym), jeśli tak też - w książkach, ale i w realnym życiu - wypowiada się faworyzowany autor powieści, wpływa to na kształtowanie wzorców i utrwalanie się tzw. skryptów. Ten z kolei proces nazywamy modelowaniem:

[...] Warunkowanie sprawcze i modelowanie są to podstawowe mechanizmy kształtowania zachowania się człowieka wykorzystywane w toku socjalizacji (wychowanie w rodzinie i poza nią). [...] Wykazano, że zarówno warunki sprawcze, czyli uczenie się przez wzmocnienia (kary i nagrody), jak i modelowanie (uczenie się przez obserwację modeli) są mechanizmami kształtującymi agresywne zachowanie [...].

Model wywiera silny wpływ zwłaszcza, gdy jest to osoba o wysokim statusie społecznym, dysponująca władzą, dochodami, ciesząca się szacunkiem innych, kompetentna (lub za taką uważana), lubiana i / lub popularna w środowisku oraz do której podmiot jest w jakiś sposób podobny (np. ta sama płeć, imię, zdolności). Jeśli obserwowane konsekwencje zachowań modela są dla niego korzystne, to modelowanie jest bardziej efektywne: tym

${ }^{46}$ W książce Barbary Krahé pt. Agresja (przekł. J. Suchecki, Gdańsk 2005, s. 90-115) można znaleźć wyniki badań nad znaczeniem gier komputerowych oraz kwestie socjalizacji i wpływu ukrytych zasad społecznych dla postępowania nie tylko nastolatków, ale i osób dorosłych.

47 Zob.: D. Kahneman, Pułapki myślenia. O myśleniu szybkim i wolnym, tł. P. Szymczak, Poznań 2002, s. 22.

${ }^{48} \mathrm{Na}$ ten temat zob.: K. Lorenz, Odwrotna strona zwierciadła. Próba historii naturalnej ludzkiego poznania, tłum. K. Wolicki, seria Biblioteka Myśli Współczesnej, http://www.objawienia.pl/ sub/lorenz/lorenz0.html, [dostęp: 2018-04-18]. Zob. też: M. Farnicka, Przemiany realizacji zadań rozwojowych. Ewolucja czy rewolucja?, s. 23. 
większe prawdopodobieństwo naśladowania go przez obserwatora. Dotyczy to wszystkich zachowań: tak prospołecznych, jak egocentrycznych i agresywnych ${ }^{49}$.

Należy podkreślić, iż modelowanie jest czymś więcej niż naśladowanie. Naśladuje się postać, która może nie być tego świadoma, że stanowi wzór, natomiast modelowanie jest zawsze aktem wychodzącym ze strony tzw. modela w kierunku tego, kto będzie na jego wpływ podatny. Są zatem dwa w tym przypadku warunki uczenia się, nabywania pewnych zwyczajów: uczymy się czegoś, gdy model jest do nas podobny (proces utożsamiania się) lub gdy staje się on autorytetem wtedy naśladujemy go i uczymy się jego zachowań. Nie bez znaczenia jest więc w powieściach Żulczyka to, o czym wcześniej pisałam: popularność i rozgłos medialny tej prozy (budowanie autorytetu pisarza), autokreacja autora, a także jego bohaterów na ,jednego z nas”, zbliżanie się do czytelników, mówienie rzekomo „ich” językiem oraz - utożsamianie głównych bohaterów z narratorami (budowanie szczególnej więzi z czytelnikiem), narracja dwutorowa (aktualna i retrospektywna), również wpływająca na pozyskiwanie zaufania i sympatii czytelnika do bohatera. Te wszystkie mechanizmy - wewnątrz- i zewnątrzliterackie odgrywają niebagatelną rolę w modelowaniu, o którym mówimy.

Resumując: jeśli człowiek, szczególnie osoba młoda, czyta książkę pełną przekleństw, wulgaryzmów, ordynarnych scen i obscenicznych bądź brutalnych obrazów, angażuje w to wiele funkcji (poznawczych, emocjonalnych itd.). Tym bardziej więc, przy wieloaspektowym zaangażowaniu umysłu, owe nieprzyzwoite słowa, sceny, obrazy i aluzje są kodowane, osadzają mu się w pamięci. W tych kategoriach zaczyna postrzegać świat, myśleć, a także - zwłaszcza w granicznych sytuacjach - artykułować myśli i stany. Bywa, że zamyka to go na świat innych ludzi, na uniwersum wyższych wartości, zubaża duchowo i intelektualnie.

Omawiana tu literatura, jak i film nie znikną, a także nie przestaną być wydawane. Nie można niczego powstrzymać i niczego zabronić. Zresztą nie chodzi ani o stygmatyzowanie ani o cenzurowanie. Tworzeniu niniejszego artykułu przyświecał zgoła inny cel; towarzyszyła - dyktowana troską - myśl, by pokazać istotny problem związany $z$ funkcjonowaniem omawianej prozy w społeczeństwie, zwłaszcza wśród młodzieży. Jaką literaturę pozostawią po sobie dla potomnych jego pokroju pisarze? Jakie świadectwo życia obyczajowego i kultury dadzą rodakom i czytelnikom z zagranicy? Co najważniejsze jednak, jak będzie żyło i jakie wartości duchowe zostawi po sobie nasze pokolenie, karmione taką prozą ( i takimi filmami), jak wyżej opisane?

${ }^{49}$ M. Farnicka, H. Liberska, D. Niewiedział, Psychologia agresji, wybrane problemy..., rozdz. 3.5. Uczenie się agresji: rola wzmocnienia i naśladownictwa, s. 63. 


\section{Bibliografia załącznikowa:}

"Gazeta Międzyszkolna”, 8 sierpnia 2016, http://www.gazetamiedzyszkolna.pl/2016/08/08/czytelnictwo-az-86-mlodych-ludzi-czyta-ksiazki/, [dostęp: 2018-04-05].

„Newsweek Polska", 21 kwietnia 2017.Zob.: http://www.newsweek.pl/styl-zycia/raport-czytelnictwaw-polsce-ile-ksiazek-czytaja-polacy-,artykuly,409201,1.html, [dostęp: 2018-04-05].

Belcer A., Promowanie czytelnictwa i bibliotek z pomysłem: przeglad wybranych akcji czytelniczych, "Podkarpackie Studia Biblioteczne", Nr 4 (2015), http://psb.ur.edu.pl/sites/default/files/pdf/ promowanie_czytelnictwa_i_bibliotek_z_pomyslem.pdf, [dostęp: 2018-06-21].

Biblia Wujka - Pismo święte Starego i Nowego Testamentu, w przekładzie polskim W.O. Jakuba Wujka S.J., tekst poprawili oraz wstępami i krótkim komentarzem opatrzyli: ks. S. Styś S.J., ks. W. Lohn S.J., Kraków 1962.

Bronk A. SVD, Krajobraz postmodernistyczny, "Ethos" Rok 9, 1996 nr 1-2 (33-34), s. 79-100.

Chrońmy dzieci i młodzież przed pornografiq, http://www.citizengo.org/pl/157711-do-ministracyfryzacji-szanowny-panie-ministrze-w-obliczu-ogolnej-dostepnosci-internetu-bez, [dostęp: 2018-03-10].

Dzięki odstawieniu używek odzyskałem pracę (https://www.youtube.com/watch?v=YRLbV947O7s - dostęp: 2018-05-11).

Farnicka M., Liberska H., Niewiedział D., Psychologia agresji, wybrane problemy, Warszawa 2016.

Farnicka M., Przemiany realizacji zadań rozwojowych. Ewolucja czy rewolucja?, Zielona Góra 2011.

Godlewska P., Świecki seksuolog: pornografia może doprowadzić do końca Kościoła!, [wywiad z Bogdanem Stelmachem], aktualizacja 18.12.2017, [dostęp: 2018-06-20].

Gołaszewska M., Kim jest artysta?, Warszawa 1986.

Gołaszewska M., Estetyka i antyestetyka, Warszawa 1984.

Gołaszewska M., Kryzys estetyki?, Kraków 1983.

Grzegorczyk A., Anioł po katastrofie, Warszawa 1995.

Horubała A., Cienka zupka Gretkowskiej, „Do Rzeczy. Tygodnik Lisickiego”, nr 35/237, 28 sierpnia - 3 września 2017, s. 40-42.

Horubała A., Żulczyk rządzi!, „Do Rzeczy. Tygodnik Lisickiego”, nr 19/221, 8-14 maja 2017, s. $42-44$ - recenzja książki, Wzgórze psów.

http://bibliotekachojnice.pl/hasla-promujace-czytanie-ksiazek/; https://zsgsiedlec.wordpress. com/2016/05/03/nagrodzone-hasla-reklamujace-biblioteke-i-czytanie/; [dostęp: 2018-06-21].

Jazownik L., Wyzwolić moc lektury. Aksjologiczno-dydaktyczny sens dzieła literackiego, Zielona Góra 2004.

Kahneman D., Pułapki myślenia. O myśleniu szybkim i wolnym, tł. P. Szymczak, Poznań 2002.

Kobieta śmierdząca człowiekiem, [z Jakubem Żulczykiem] rozmawiały A. Drotkiewicz i A. Dziewit-Meller, „Wysokie Obcasy”, 30 listopada 2008, http://www.wysokieobcasy.pl/wysokie-obcasy/1,96856,5992077,Kobieta_smierdzaca_czlowiekiem.html, [dostęp: 2018-05-06].

Koch S., Psychologia wobec przejawiających się koncepcji jednolitej wiedzy, tłum. R. Stachowski, w: Behawioryzm i fenomenologia, red. T.W. Wann, (różni tłumacze), Kraków 2002, s. 11-62.

Kopaliński W., Słownik wyrazów obcych i zwrotów obcojęzycznych, wydanie jedenaste, Wiedza Powszechna, Warszawa 1980.

Kopaliński W., Słownik wyrazów obcych izwrotów obcojęzycznych, wydanie jedenaste, Warszawa 1980. Koszewska A., Koncepcja antropologiczna zawarta w rozprawie Osoba i czyn Karola Wojtyły jako podstawa refleksji o twórczości artystycznej, w: Kultura nie tylko literacka. W kręgu myśli Karola Wojtyły-Jana Pawła Il, część 2, „Scripta Humana” t. 10, redakcja naukowa D. Kulczycka i A. Seul, Zielona 2018.

Krahé B., Agresja, przekł. J. Suchecki, Gdańsk 2005. 
Lorenz K., Odwrotna strona zwierciadła. Próba historii naturalnej ludzkiego poznania, tłum. K. Wolicki, seria Biblioteka Myśli Współczesnej, http://www.objawienia.pl/sub/lorenz/lorenz0.html, [dostęp: 2018-04-18].

Lyotard J.-F., Kondycja ponowoczesna. Raport o stanie wiedzy, przeł. M. Kowalska i J. Migasiński, Warszawa 1997.

Mądrzycki T., Psychologiczne prawidłowości kształtowania się postaw, Warszawa 1977.

Mead G. H., Umysł, osobowość i społeczeństwo, przeł. Z. Wolińska, wstępem opatrzyła A. Kłoskowska, Warszawa 1975.

Niwińska A., Ocalić od porno, „Do Rzeczy. Tygodnik Lisickiego", nr 2/255, z 8-14 stycznia 2018 r., s. 36-37. Bogdan Stelmach, seksuolog: Pornografia powoduje przewlekłą chorobę mózgu, 10 lutego 2017, http://telewizjarepublika.pl/bogdan-stelmach-seksuolog-pornografia-powodujeprzewlekla-chorobe-mozgu,44417.html, [dostęp: 2018-06-20].

O wartościowaniu w badaniach literackich, pod red. S. Sawickiego, W. Panasa, Lublin 1986.

Sawicki S., Chrześcijańskie wartości poezji Norwida, Lublin 1986.

Sawicki S., Wartość - sacrum - Norwid, Lublin 1994.

Shattuck R., Wiedza zakazana. Od Prometeusza do pornografii, przekład M. Borowska, Kraków 1999.

Skinner B. F., Poza wolnościq i godnościq, przeł. W. Szelenberger, przedmową opatrzył J. Szacki, Warszawa 1978.

Skinner B. F., Pół wieku behawioryzmu, tłumaczenie Jerzy Siuta, w: Behawioryzm i fenomenologia..., s. 99-135.

Słowacki J., Beniowski, oprac. A. Kowalczykowa, BN seria I nr 13/14, Wrocław 1996.

Stróżewski W., W kręgu wartości, Kraków 1992.

Szahaj A., Co to jest postmodernizm?, „Ethos" Rok 9, 1996 nr 1-2 (33-34), s. 63-78.

Tavris C., Wade C., Psychologia. Podejścia oraz koncepcje, przekł. J. Gilewicz, Warszawa 1999.

Taylor Ch., Etyka autentyczności, przekład A. Pawelec, Społeczny Instytut Wydawniczy Znak, Kraków 1996.

Wóycicki K., Rozbiór literacki w szkole. Podręcznik dla nauczycieli, Warszawa 1921.

Wysocki G., Nie jestem polskim Kingiem ani Tarantino. Jak to w ogóle brzmi?, [wywiad z Jakubem Żulczykiem], 10 listopada 2017, https://magazyn.wp.pl/artykul/jakub-zulczyk-nie-jestempolskim-kingiem-ani-tarantino-jak-to-w-ogole-brzmi, [dostęp: 2018-03-12].

Żulczyk J., Instytut, Kraków 2010.

Żulczyk J., Radio Armageddon, Warszawa 2015.

Żulczyk J., Ślepnąc od świateł, Warszawa 2015.

Żulczyk J., Wzgórze psów, Warszawa 2017.

Żulczyk J., Zmorojewo. Powieść fantastyczno-przygodowa, Warszawa 2011.

Żulczyk J., Zrób mi jakq̨ś krzywdę, Warszawa 2018.

\section{Streszczenie}

Autorka artykułu stawia śmiałą tezę, że współczesna literatura polska w wielu przypadkach (a na pewno w przypadku omawianej tu prozy i scenariuszy pisanych przez Jakuba Żulczyka) nie diagnozuje jedynie sytuacji obyczajowej, ale również stwarza pewne wzorce zachowania. Używając pojęcia „przemocy symbolicznej” (ukonstytuowanego przez Pierre'a-Félixa Bourdieu), twierdzi, że takie pisarstwo generuje również patologiczne i szkodliwe społecznie zachowania. Szczególnie niebezpiecznym moralnie zjawiskiem jest narastająca w literaturze wulgaryzacja języka. Jest to w istocie błędne koło: społeczeństwo podpowiada pewne wulgarne środki wyrazu; pisarz, nagminnie je stosując, daje przyzwolenie by właśnie tak, a nie inaczej wysławiać się i postępować. Uczenie się niewłaściwych zachowań zachodzi dzięki procesom, które psychologia nazywa torowaniem (ang. priming), modelowaniem i budowaniem skryptów (ang. scripts). Opisywane w artykule zjawiska, 
chociaż dotyczą przede wszystkim prozy polskiej, mają charakter uniwersalny. Zainteresowanie czytelnika z zagranicy mogą wzbudzić zwłaszcza psychologiczne konsekwencje odbioru literatury popularnej przejawiającej wymienione przez autorkę tendencje.

Słowa kluczowe: proza polska, aksjologia, recepcja dzieła literackiego, modelowanie, torowanie umysłu,skrypty

\section{Axiological problems emerging from contemporary Polish literature. The case of Jakub Żulczyk's prose}

\section{Summary}

The author of the article proposes the thesis that contemporary Polish literature, in many instances that include the prose and screenplays of Jakub Żulczyk, does not merely diagnose a particular moral condition of Polish society, but also generates it. Pierre F. Bourdieu's term „symbolic violence” aptly describes this process, which involves the creation of negative or pathological behaviours. What is particularly dangerous is an increasing vulgarization of literary language, which proceeds according to the principle of the vicious circle: the author is initially inspired by the language of the street, which he subsequently enriches with new vulgar expressions. Those are, in turn, incorporated in the language. The impact of this kind of literature on the readers appears to be consistent with processes recognized by psychology such as priming, modelling, and developing scripts. Although the article makes references to Jakub Żulczyk〉s prose, the phenomena it describes are not restricted to Polish literature, but universal. What might interest foreign readers are the psychological consequences of reading popular novels which exhibit the features and tendencies on which the article focuses.

Key words: Polish prose, axiology, reception of a literary work, modeling, priming, scripts 